\title{
Volatility-adjusted Performance An Alternative Approach to Interpret Long-run Returns
}

\author{
Jakobsen, Jan Bo; Voetmann, Torben
}

Document Version

Final published version

Publication date:

2000

\section{License \\ CC BY-NC-ND}

Citation for published version (APA):

Jakobsen, J. B., \& Voetmann, T. (2000). Volatility-adjusted Performance: An Alternative Approach to Interpret Long-run Returns. Institut for Finansiering, Copenhagen Business School. Working Papers / Department of Finance. Copenhagen Business School No. 2000-3

Link to publication in CBS Research Portal

\section{General rights}

Copyright and moral rights for the publications made accessible in the public portal are retained by the authors and/or other copyright owners and it is a condition of accessing publications that users recognise and abide by the legal requirements associated with these rights.

\section{Take down policy}

If you believe that this document breaches copyright please contact us (research.lib@cbs.dk) providing details, and we will remove access to the work immediately and investigate your claim. 
WP 2000-3

Volatility-Adjusted Performance:

An Alternative Approach to Interpret Long-Run Returns

af

Jan Jakobsen \& Torben Voetmann

INSTITUT FOR FINANSIERING, Handelshøjskolen i København

Solbjerg Plads 3, 2000 Frederiksberg C

tlf.: 38153615 fax: 38153600

DEPARTMENT OF FINANCE, Copenhagen Business School

Solbjerg Plads 3, DK - 2000 Frederiksberg C, Denmark

Phone (+45)38153615, Fax (+45)38153600

www.cbs.dk/departments/finance

ISBN 87-90705-33-5

ISSN 0903-0352 


\title{
Volatility-Adjusted Performance
}

\section{An Alternative Approach to Interpret Long-Run Returns}

\author{
Jan Jakobsen* \\ Department of Finance, Copenhagen Business School \\ and \\ Torben Voetmann \\ Department of Finance, The Wharton School
}

December 1999

\begin{abstract}
:
This paper investigates long-run returns by utilizing log-normal distribution properties of cross-sectional buy-and-hold returns. We decompose expected cross-sectional buyand-hold returns into transformed mean components and volatility components. This decomposition shows that the volatility component contributes positively to the rightskewed buy-and-hold returns due to Jensen's inequality. Given the log-normal distribution properties are fulfilled, the method can be applied to any type of long-horizon event study of security performance. We apply the method to IPO stocks and SEO stocks listed on the Copenhagen Stock Exchange. Using traditional standard techniques, we find that IPO stocks and SEO stocks under perform relative to the market after five years by 27.3 percent and 21.4 percent, respectively. However, the volatilityadjusted performance measure shows that the IPO stocks and SEO stocks under perform relative to the market after five years by 43.7 percent and 38.1 percent, respectively.
\end{abstract}

Keywords: Wealth relatives; buy-and-hold returns; equity offerings JEL classification: G14, G32

\footnotetext{
* Corresponding author: Jan Jakobsen, Department of Finance, Copenhagen Business School, Solbjerg Plads 3, DK-2000 Frederiksberg, Denmark. Phone: (+45)38153619; fax: (+45)38153600; e-mail: ii.fi@cbs.dk. We have benefited from the comments of a seminar at the Center of Analytical Finance and the Nordic Workshop on Corporate Finance. Any comments are gratefully appreciated. The usual disclaimer applies.
} 


\section{Introduction}

The right-skewed distribution of long-run returns causes an inference problem of the significance of security performance. Fama (1998) addresses this problem as a "badmodel" problem in studies of long-run returns, arguing that the error in the expected return grows faster with time than the volatility does. Lyon, Barber and Tsai (1999) address the problem using a skewness-adjusted t-statistic for testing average long-run returns. However, to the best of our knowledge, none are actually testing the distribution properties of the cross-sectional long-run returns. Therefore, we question the validity of prior tests of long-run abnormal returns.

The contribution of this paper is twofold. First, we formalize the skewness problem utilizing the properties of the log-normal distribution to describe the expected buy-andhold returns. The methodology hinges on the cross-sectional distribution properties of long-run returns. The log-normal distribution of cross-sectional buy-and-hold returns of wealth relatives (see Ritter (1991) and Loughran and Ritter (1995)) allows for a decomposition of the expected mean buy-and-hold abnormal return into its transformed mean and volatility component. The decomposition provides well-specified and testable maximum likelihood estimators. Second, the method provides an alternative approach to understand and interpret long-run security performance. Applying the method on a sample of unseasoned- and seasoned-equity offerings shows that the volatility-adjusted performance measure provides a better inference of security performance than the usual measure of buy-and-hold abnormal return.

We calculate the cross-sectional averages of the buy-and-hold returns using three different methods. The first method, the most commonly used, is a simple cross-sectional arithmetic average calculation that does not adjust for right skewed long-run returns. The second method is to calculate the average cross-sectional return as the expected value of log-normally distributed buy-and-hold returns. The expected value of lognormally distributed buy-and-hold returns cannot be tested directly due to an upward bias caused by the volatility. The third method decomposes the expected crosssectional mean buy-and-hold returns into transformed mean components and volatility 
components. This decomposition of the average cross-sectional mean buy-and-hold return in levels provides a more distinctive interpretation of the under performance or over performance. This is possible because the decomposition of the average crosssectional buy-and-hold return accounts for the impact that originates from the transformed mean component and the positive volatility component.

Using a simple arithmetic cross-sectional average of the wealth-relative measure shows that 142 IPO stocks and 413 SEO stocks under perform relative to the market after five years by 27.3 percent and 21.4 percent, respectively. However, looking at the market-to-security wealth-relatives show that the market out performs IPO stocks and SEO stocks by an average of 152.6 percent and 128.4 percent, respectively. The large differences between the two wealth relatives (market-to-security and security-tomarket) are due to the volatility component. The cross-sectional average buy-and-hold return of the market-to-security ratio is amplified by the volatility component while the security-to-market wealth relative ratio is dampened by the volatility component. Those cross-sectional averages are contaminated by the right-skewness bias. Adjusting the expected cross-sectional mean buy-and-hold return for the volatility component, IPO stocks and SEO stocks under perform relative to the market by 43.7 percent and 38.1 percent after five years. Equivalently, the market out performs IPO stocks and SEO stocks by 77.5 percent and 61.5 percent, respectively. This under (out) performance is statistically significant at the one-percent critical level of significance.

Applying the volatility-adjusted performance measure on a sample of hot (cold) period equity issues show that hot issues experience significant long-run under performance compared to cold issue periods. ${ }^{1}$ The results show that the under performance after one year is similar for hot and cold issues while after five years hot issues under perform significantly by 50.0 percent and cold issues under perform insignificantly by 22.6 percent. This indicates that investing in firms going public in a cold issue period is better in the long run than investing in firms going public in a hot issue period. Catego-

\footnotetext{
${ }^{1}$ Loughran, Ritter and Rydqvist (1994) document the tendency of high initial returns and volume after a period of high stock market performance. Jakobsen and Sørensen (1999) also document that high initial returns are inversely related to the buy-and-hold returns and with negative long-run returns over a fiveyear period.
} 
rized IPO stocks by market capitalization provide some evidence that the lowest quartile under perform more than the highest quartile. Volatility-adjusted performance measure confirms that small capitalization issues under perform relative to larger capitalization issues. The out performance after five years is not statistically significant at a five-percent critical level of significance for the largest quartile. This indicates that under performance may be concentrated in small capitalization firms. Categorizing SEO stocks by the proceed-to-market value ratio shows that the market out performs all quartiles after five years and this out performance is statistically significant at a one-percent level. This indicates that the under performance of the proceed-to-market capitalization does not depend on the size of the capitalization.

The structure of the paper is as follows. Section II discusses methodological problems of measuring long-run returns. Section III introduces the methodology that is used for testing and measuring long-run buy-and-hold returns of wealth relatives. Section IV presents prior findings of long-run security performance and the empirical results using the method on IPO and SEO stocks, a hot (cold) issue period, and on a sample partition by market capitalization. Section $\mathrm{V}$ provides the concluding remarks.

\section{Methodological Problems of Measuring Long-Run Returns}

A number of studies find significant over (under) performance by testing long-run buyand-hold returns. However, conventional test statistics used for testing are not necessarily valid due to distribution properties of the buy-and-hold returns. Recently, Fama (1998) argues that none of the documented long-run performance studies actually tests for whether securities on average are under performing or over performing. ${ }^{2}$ Fama argues that the market efficiency hypothesis is intact because the anomalies disappear with changes in the estimation model of the expected returns, i.e. the estimation meth-

\footnotetext{
${ }^{2}$ See Agrawal, Jaffe and Mandelker (1992) for mergers and acquisitions, Ikenberry, Lakonishok and Vermaelen (1995) for share repurchases, Michaeley, Thaler and Womach (1995) for dividend initiations and omissions, Speiss and Affleck-Graves (1995) for seasoned equity offerings, Loughran and Vijh (1997) for corporate acquisitions, and Ritter (1991), Aggarwal and Rivioli (1990), Loughran and Ritter (1995), Jakobsen and Sørensen (1999) for initial public offerings. The results from various kinds of event studies show that over reactions in the marketplace is as common as under reactions, therefore, Fama (1998) argues that the post-event reversals are as frequent as the post-event continuations of preevent returns.
} 
odology may cause long-run anomalies. Also, inference of long-run returns are problematic due to unavoidable "bad-model" problems caused by incomplete models that are applied to estimate expected returns and sample-specific patterns in average returns which are caused by systematic deviations.

The commonly used event-study methodology $(C A R)$ to estimate long-run abnormal returns causes severe problems for testing and interpreting long-run security performance. Conrad and Kaul (1993) document a potential bias (upward or downward) nduced by cumulative abnormal returns over the long run, i.e. the long-run cumulative adjusted returns become potentially biased. Barber and Lyon (1997a) and Kothari and Warner (1997) find severe problems related to the fact that abnormal returns are nonnormally distributed as they become right skewed after a period of time. Symmetric and independently distributed periodic returns induce right skewness and autocorrelation in accumulated returns. This right skewness arises due to the accumulation method of buy-and-hold returns. Fama (1998) address problems concerning mis-specifications that arise from "re-balancing" bias, "new listing" bias, and right "skewness" biases. These problems affect the conventional test methods and yet many empirical results make inference based on incorrect test statistics. ${ }^{3}$ Barber and Lyon (1997a) argue that the mis-specification causes the inference based on long-run returns to be incorrect. They argue that it is possible to achieve well-specified test statistics when the usual BHAR is corrected by matching sample firms with control firms of similar size and book-to-market ratios. ${ }^{4}$ Kothari and Warner (1997) suggest a parametric shift in the event window that influences the tests of accumulated returns, e.g. the interference must include the possible increase in variability of abnormal returns. Lyon, Barber and Tsai (1999) suggest a correction of the usual t-test statistic to capture the skewness of the distribution of the buy-and-hold abnormal returns. However, the design of the benchmark is important for the applicability of the skewness-adjusted t-statistics.

\footnotetext{
${ }^{3}$ See Conral and Kaul (1993), Barber and Lyon (1997), Canina, Michaely, Thaler, and Womack (1997), Kothari and Warner (1997), Cowan and Sergeant (1997), Lyon, Barber and Tsai (1999) for warnings about the buy-and-hold return methodology used to estimate abnormal returns.

${ }^{4}$ Fama (1998) argues that corrections of expected returns using a matching approach based on size and $\mathrm{BE} / \mathrm{ME}$ does not limit bad-model problems. Abnormal returns vary whether matching is based on size or size and BE/ME. Fama (1998) argues that this matching approach does not capture the cross-sectional variation in expected returns. Therefore, a matching approach for expected returns is not a panacea for
} 


\section{Methodology}

The following four sub-sections describe the methodology used in this paper. Subsection A provides an introduction to the event-study method and its problem in measuring long-run returns. Sub-section A also examines the cross-sectional distribution properties of the long-run returns of the securities and the benchmark. Sub-section B describes, for the long run, the methodology of designing a variable transformation that exhibits log-normally distributed buy-and-hold returns (e.g. wealth relatives). We investigate wealth-relative transformation of the security return series and the benchmark return series. In sub-section $\mathrm{C}$, we decompose the expected average crosssectional long-run returns into transformed mean and volatility components. Finally, sub-section D specifies the tests of the components. ${ }^{5}$

\section{A. Short-run Returns versus Long-run Returns}

Event studies are performed using periodic returns (e.g. daily, weekly or monthly) over a pre-event, event, and post-event window. Define $r_{i t}$ as the simple periodic return of security $i$ over period $t$. The expected return of security $i$ over period $t$ based on the information set $\Omega_{t}$ is $E\left(r_{i t} \mid \Omega_{t}\right)$. $\Omega_{t}$ is the relevant information set, e.g. pre-event or postevent windows, of the security performance model. Subtracting the expected return from the observed return is defined as the abnormal return $A R_{i t} \equiv r_{i t}-E\left(r_{i t} \mid \Omega_{t}\right)$ over period $t$. The event window can vary from a short-horizon period (few days) to a longhorizon period (36 to 60 months). To make inference of security performance over an event window with time horizon $\tau$ the cumulative abnormal return $(C A R)$ can be used and it is calculated as:

$$
C A R_{i, \tau}=\sum_{t=1}^{\tau} A R_{i t}
$$

bad-model problems. In particular in long-run event studies because the standard error in abnormal return increases with the number of months.

5 Jakobsen and Sørensen (1999) propose the decomposition of long-run returns using a geometric Brownian motion. 
If there are $N$ securities, i.e. $i=\{1, \ldots, N\}$, dividing the sum over $i$ of all the $C A R_{i, \tau}$ by $N$ provides the cumulative average abnormal return over the time horizon $\tau\left(C A A R_{\tau}\right)$. $C A R$ only adds-up periodic returns and does not capture the compounding effect of periodic returns. The measure of buy-and-hold returns explicitly captures the compounding of periodic returns. By using the buy-and-hold measure for measuring abnormal returns, we can apply different approaches. The traditional approach to measure abnormal returns of a security $i$ against some benchmark (e.g. the expected return) over the time horizon $\tau$ is:

$$
B H A R_{i, \tau}=\prod_{t=1}^{\tau}\left(1+r_{i t}\right)-\prod_{t=1}^{\tau}\left(1+E\left(r_{i t} \mid \Omega_{i t}\right)\right)
$$

Over the long run, the buy-and-hold abnormal return $\left(B H A R_{i, \tau}\right)$ approach reflects a more realistic measure of security $i$ 's performance than the $C A R_{i, \tau}$ approach. Similar to the $C A A R$ approach, an average of the cross-sectional $B H A R_{i, \tau}$ can be calculated. Both methods $(C A R$ and $B H A R)$ require an appropriate benchmark against which the sample-specific securities can be compared. Usual applied test statistics of both the CAR and the BHAR approach apply the ratio of the sample-specific mean to its estimated standard deviation. However, it is difficult to achieve unbiased test statistics of both the mean and the standard deviation estimates. For the $C A R$ approach, the statistical power in event studies is not the main issue since it approaches one when $N$ increases but the lack of the compounding effect is a problem in the long run. ${ }^{6}$ For the BHAR approach, the compounding effect is intact in the long run but usually applied test statistics are invalid due to the severe right-skewed distribution of the BHAR measure. Therefore it is necessary to address the underlying distribution properties of long-run returns.

\footnotetext{
${ }^{6}$ The statistical power increases because the mean $C A R$ increases with $N$ while the standard error of $C A R$ increases with $N^{1 / 2}$.
} 


\section{B. Buy-and-Hold Returns}

Long-run returns are measured by the method of compounding returns, i.e. buy-andhold returns. The buy-and-hold return is calculated for each security, $i$, from the announcement day to some future date $T$. An initial amount $W_{i, 0}$ is invested in each security, $i$, with a stochastic periodic (monthly) return, $r_{i, t}$, that is realized at the end of period $t$. The invested amount accumulates after $T$ periods to $W_{i, T}$ :

$$
W_{i, T}=W_{i, 0} \cdot \prod_{t=1}^{T}\left(1+r_{i, t}\right)
$$

Without loss of generality, the initial amount $W_{i, 0}$ can be set equal to one and the buyand-hold return is equal to $\prod_{t=1}^{T}\left(1+r_{i, t}\right)-1$. Buy-and-hold returns will typically be rightskewed distributed, even if the periodic returns are symmetrically distributed, and that necessitates an investigation of the distribution properties. The wealth relative between two accumulated values is the ratio between the wealth $W_{i, T}$ of investing in a security and the wealth $W_{m, T}$ of investing in the market indexafter $T$ periods. This accumulated wealth relative follows the spirit of Ritter (1991) and Loughran and Ritter (1995). ${ }^{7}$ The wealth relative can be measured as either the market-to-security ratio, $W_{m-i, T}$ $=\left(W_{m, T} / W_{i, T}\right)$, or the security-to-market ratio, $W_{i-m, T}=\left(W_{i, T} / W_{m, T}\right)$. The accumulated wealth relative (security-to-market) after $T$ months is:

$$
W_{i-m, T} \equiv W_{i-m, 0} \cdot \frac{\prod_{t=1}^{T}\left(1+r_{i, t}\right)}{\prod_{t=1}^{T}\left(1+r_{m, t}\right)}=W_{i-m, 0} \cdot \prod_{t=1}^{T} \frac{\left(1+r_{i, t}\right)}{\left(1+r_{m, t}\right)}
$$

\footnotetext{
${ }^{7}$ Ritter (1991) and Loughran and Ritter (1995) use the wealth relatives differently by taking the average in the numerator and the denominator. Our approach is more applicable because the wealth relative is log-normal distributed. An alternative to the wealth relative is the transformed buy-and-hold abnormal return $(T-B H A R)$ where we compounded abnormal returns over time, which can also be accepted lognormal distributed (see appendix A). The T-BHAR states that an investor holds a long position in the market index and a short position in the equity offering in which the proceed are realized monthly and reinvested assuming no transaction costs.
} 
where $i=\{1, \ldots, N\}$ and $T=\{1, \ldots, 60\}$. Taking the logarithm of the wealth relative and assuming that $\left(W_{i, 0} / W_{m, 0}\right)=1$ the expression becomes:

$$
\log \left(W_{i-m, T}\right)=\sum_{t=1}^{T} \log \left(1+r_{i, t}\right)-\sum_{t=1}^{T} \log \left(1+r_{m, t}\right)
$$

If the logarithms of the periodic (monthly) gross returns are normally distributed the buy-and-hold returns of the securities, the benchmarks, and the wealth relatives will be log-normally distributed. Even if the securities' or the benchmark's periodic returns are not normally distributed it may still be the case that subtracting the periodic (monthly) returns of the security from the benchmark turns out to be normally distributed. In other words, in [5] the left-hand side may be normally distributed even if the individual terms on the right-hand side are not normally distributed. The transformation of wealth relatives from logarithmic values to level values using exact expressions in discrete time is:

$$
W_{i-m, T}=W_{i-m, 0} \cdot e^{\sum_{t=1}^{T} \log \left(1+r_{i, t}\right)-\log \left(1+r_{m, t}\right)}
$$

If the wealth relative is log-normally distributed an inherent relationship exists between the geometric Brownian motion model and the development in the wealth relatives. The geometric Brownian motion model represents an explicit structure on the wealth relative that describes the development of the buy-and-hold returns over time. The common interpretation of the geometric Brownian motion model calls for constant drift and volatility parameters over time. However, if the purpose is to investigate cross-sectional buy-and-hold returns at different time horizons and allowing the drift parameter and the volatility parameter to vary over time it is not necessary to use the geometric Brownian motion model. It is sufficient to utilize the log-normal distribution properties of long-run returns, i.e. Jensen's inequality. Though we do not need to describe the cross-sectional buy-and-hold returns with the geometric Brownian motion, we show the expression of the wealth relative (security-to-market): 


$$
W_{i-m, T}=W_{i-m, 0} \cdot e^{\left(\mu_{T}-\frac{1}{2} \sigma_{T}^{2}\right) \cdot T+\sigma_{T} \cdot Z_{T}}
$$

where $\mu_{T}=\alpha_{T}+\frac{1}{2} \sigma_{T}^{2}$. The parameters $\alpha_{T}, \mu_{T}$, and $\sigma_{T}$ are constants and $\left\{Z_{t}\right\}_{t \geq 0}$ is a Wiener process with $\mathrm{d} Z_{t} \sim N(0, d t)$. Expression [7] allows the constants $\alpha_{T}$ and $\sigma_{T}$ to vary dependent on the time horizon $T$. This flexibility is based on the assumption that the cross-sectional means at any given time horizon $T$ can be treated as independent observations.

\section{Decomposing the Wealth Relative}

Given that the wealth relatives (security-to-market) follows a log-normal distribution, the logarithm of the wealth relative is normally distributed with transformed mean $\alpha_{T}$ $\cdot T$ and standard deviation $\sigma_{T} \sqrt{T}$. The expected mean buy-and-hold return of the wealth relative in levels is log-normally distributed with the expected mean: ${ }^{8}$

$$
\begin{aligned}
E\left(W_{T}\right)= & e^{\mu_{T} \cdot T}=e^{\alpha_{T} \cdot T+\frac{1}{2} \sigma_{T}^{2} \cdot T} \\
& =\underbrace{e^{\alpha_{T} \cdot T}}_{\begin{array}{c}
\text { Transformed } \\
\text { mean component }
\end{array}} \cdot \underbrace{e^{\frac{1}{2} \sigma_{T}^{2} \cdot T}}_{\begin{array}{c}
\text { Volatility } \\
\text { component }
\end{array}}
\end{aligned}
$$

From expression [8] it is observed that the volatility component implies an upward bias on the average wealth relative. This volatility effect is always positive and identical irrespective of the wealth-relative measure (security-to-market or market-to-security). Therefore, it is necessary to adjust the expected average cross-sectional wealth relative for the volatility component in order to infer coherent long-run security performance. As the volatility component imposes an upward bias on the expected mean buy-andhold return, we decompose the cross-sectional mean of the wealth-relative ratio, $e^{\mu_{T} \cdot T}$, into its transformed mean component, $e^{\alpha_{T} \cdot T}$, and its volatility component, $e^{\frac{1}{2} \sigma_{T}^{2} \cdot T}$. The

\footnotetext{
${ }^{8}$ In general, the expected value in expression [8] does not equal the simple arithmetic average of crosssectional buy-and-hold returns (method 1 , above).
} 
geometric Brownian motion model representation explicitly depicts the transformed mean component and the volatility component. This decomposition also captures the feature that the periodic (monthly) returns may be symmetric and independently distributed while the buy-and-hold returns of the wealth relatives exhibit right skewness.

\section{Tests of the Transformed Mean and Volatility Components}

The wealth relative that is described in expression [7] is log-normally distributed. Thus, when the logarithm is taken it becomes normally distributed:

$$
\log \left(W_{i-m, T}\right) \sim\left(\alpha_{T} \cdot T, \sigma_{T}^{2} \cdot T\right)
$$

Given that the logarithm of the wealth relative is normally distributed, we can estimate the transformed mean parameters and variance parameters:

$$
\begin{gathered}
\hat{\alpha}_{T}=\frac{1}{T \cdot N} \sum_{i=1}^{N} \log \left(W_{i-m, T}\right) \\
\hat{\sigma}_{T}^{2}=\frac{1}{T \cdot(N-1)} \sum_{i=1}^{N}\left(\log \left(W_{i-m, T}\right)-\hat{\alpha}_{T} \cdot T\right)^{2}
\end{gathered}
$$

The parameter estimates: $\hat{\alpha}_{T}$ and $\hat{\sigma}_{T}^{2}$ are marginal parameter estimates at any point in time. The marginal parameter estimates are only based on the expected cross-sectional wealth relative at time $T$. Both the marginal parameter estimates at time $T$ are treated independently of marginal parameter estimates of other time periods. Therefore, serial correlation or other time-series dependencies do not influence the marginal parameter estimates. At time $T$, the transformed mean and standard deviation of $\log \left(W_{i-m, T}\right)$ are $\hat{\alpha}_{T} \cdot T$ and $\hat{\sigma}_{T} \cdot \sqrt{T}$, respectively. The marginal estimates $\hat{\alpha}_{T} \cdot T$ and $\hat{\sigma}_{T} \cdot \sqrt{T}$ can be tested against alternatives using the cross-sectional wealth relatives at time $T$. For example, two independent hypotheses could be the following:

$$
\mathrm{H}_{0}: \alpha_{T} T=0, \quad \text { versus } \mathrm{H}_{1}: \alpha_{T} T \neq 0
$$

or 


$$
\mathrm{H}_{0}: \sigma_{T} \cdot \sqrt{T}=\lambda, \quad \text { versus } \quad \mathrm{H}_{1}: \sigma_{T} \cdot \sqrt{T} \neq \lambda
$$

where $\lambda$ can be any positive value. The marginal confidence interval of the marginal estimate $\alpha_{T} T$ is $t$-distributed at time $T$ and the marginal confidence interval of the marginal estimate $\hat{\sigma}_{T} \cdot \sqrt{T}$ is $\chi^{2}$-distributed at time $T$ both with $N-1$ degrees of freedom. The marginal estimates can be transformed back to levels through the exponential function and the resulting expected mean buy-and-hold returns can be compared to the wealth relative. This ensures that the transformed mean components, $e^{\hat{\alpha}_{T} \cdot T}$, and the volatility components, $e^{\frac{1}{2} \hat{\sigma}_{T}^{2} \cdot T}$ can be compared to the expected mean buy-and-hold returns, $e^{\mu_{T} \cdot T}$.

To summarize, the methodology, used to investigate cross-sectional buy-and-hold returns of wealth relatives, identifies log-normally distributed long-run returns and decomposes the expected average cross-sectional buy-and-hold returns into transformed mean components and volatility components. Adjusting for the volatility component, the transformed mean component provides a testable and correct estimate of long-run security performance. ${ }^{9}$

\section{Results}

In the following section, we apply the method that implements the volatility-adjusted performance measures to equity offerings stocks. We partition the unseasoned and seasoned equity offerings in different groups and test the expected volatility-adjusted performance. We apply two approaches, the market model and the market-adjusted model, to infer the performance of unseasoned and seasoned equity offerings stocks.

\footnotetext{
9 Appendix B describes the relationship between the geometric Brownian motion and the log-normal distribution.
} 


\section{A. Long-Run Performance of IPO and SEO Stocks}

Empirically, unseasoned (IPO) and seasoned (SEO) equity offerings have been $\mathfrak{e}$ ported to under perform in the long run, and this under performance continues several years after the equity issues. In the United States, the long-run market adjusted returns are reported to be negative during the three- and five-year period after the issue (see Ritter (1991), Eckbo and Masulis (1995), Loughran and Ritter (1995), and Spiess and Affleck-Graves (1995)). Loughran, Ritter, and Rydqvist (1994) compare unseasoned equity offerings for 24 countries that demonstrate similar patterns, although some find positive long-run returns (see Loderer and Zimmermann (1988), Bøhren, Eckbo and Michalsen (1997), Bigelli (1997), and Dubois and Jeanneret (1998)). ${ }^{10}$ Lewis (1993) reports a three-year under performance in IPO stocks from the United Kingdom and the IPO firms experience an average 30 percent loss of value compared to the market. Lee, Taylor and Walter's (1996) result also shows that the market-adjusted cumulative average returns from Australian IPO stocks under perform over a three-year period. ${ }^{11}$

Ritter (1991) and Spiess and Affleck-Graves (1995) state that the persistency of longrun returns after equity offerings is puzzling (this paper, however, suggest that the volatility is important in explaining the observed persistence of long-run returns). Ritter (1991) examines 1,526 IPO stocks and finds a negative 15.08 percent average cumulative matching firm-adjusted return after 36 months. Comparing returns with firms of similar size and industry, the average IPO stock's cumulative abnormal returns are negative 26 percent. Ritter (1991) argues that the result is consistent with investors being overoptimistic about potential growth firms. Loughran and Ritter (1995) examine the five-year long-run return for 4,753 IPO stocks and 3,702 SEO stocks in the United States during 1970-1990. The average long run IPO return adjusted for size and industry under performed with 20 percent after three years. While the SEO long-run returns under perform with 22 percent. Both studies calculate buy-and-hold returns and argue that the results show a deviation from the long-run efficient market theory. Spi-

\footnotetext{
${ }^{10}$ For comprehensive surveys see Smith (1986), Eckbo and Masulis (1995), Ibbotson and Ritter (1995) for IPO stocks, and Eckbo and Masulis (1995) for SEO stocks. Other findings from non-US studies showing positive returns are Hietala and Löyttyniemi (1991) for Finland, Dhatt, Kim and Mukherji (1996) for Korea, Tsangarakis (1996) for Greece, and Kang and Stulz (1996) for Japan.

${ }^{11}$ Corresponding results are found in Aggarwal et al. (1993) for Brazil and Chile, Keloharjo (1993) for Finland, Kunz and Aggarwal (1994) for Switzerland, and Page and Reyneke (1997) for South A frica.
} 
ess and Affleck-Graves (1995) examine 1,246 seasoned equity offerings during the period 1975-1989 and find a negative abnormal return of 22 percent when compared to matching firms over a five-year post-event period. The results are persistent when adjusting for trading system, offer size, and the issuing firm's age and book-to-market value.

There are several similarities between IPO stocks and SEO stocks, e.g. transfer of ownership rights from existing to new shareholders. Presently, there exists no convincing theory that explains long-run under performance in unseasoned and seasoned equity offerings. The most promising explanation concerns an argument about investors' overreaction and over optimistic behavior to the information revealed through equity offerings (See Loughran and Ritter (1995) and Jakobsen and Sørensen (1999)). Spiess and Affleck-Graves (1995) examine the abilities of managers to take advantages and exploit overvaluation. They argue for an overvaluation exploitation opportunity for managers in SEO stocks if it is possible in IPO stocks, i.e. their results confirm that managers issue equity when the stock is overvalued because they are able to take advantage of firm-specific information. Comparing the under performance of IPO stocks and SEO stocks shows support for Spiess and Affleck-Graves (1995) result that managers, also, can exploit overvaluation opportunities in SEO stocks, i.e. it is not only the vast information asymmetry in IPO stocks that allow managers to exploit overvaluation. ${ }^{12}$ Empirically, the findings in this paper complement Spiess and Affleck-Graves's (1995) result and the methodology supports the exploitation explanation. However, the task of future research is still to develop a consistent theory.

\section{B. Data Material}

We construct a sample by gathering information of unseasoned and seasoned equity offerings during the period 1983-1998. The data source is Account Data that contains information on equity offerings by firms that are listed on the Copenhagen Stock Ex-

\footnotetext{
12 Two alternative and promising explanations are the theory of investor sentiment. Barberis, Shleifer and Vishny (1998) and Daniel, Hirshleifer and Subrahmanyam (1998) explain long-run performance with behavioral model of investor sentiment. The behavior models provide an alternative explanation of investors' behavior but not a better explanation of the long-run anomalies.
} 
change, and it identifies the type of equity offering and its characteristics. ${ }^{13}$ For the equity offering to be included in the sample it must meet the following three criteria: 1) the issue must be a primary offering, i.e. offerings that include preferred and secondary shares are excluded; 2) joint offerings are excluded; and 3) the offering firm must be listed on the Account Data's security price information at the time of the issue. In addition, we evaluate the pricing information to identify and exclude any equity offerings in which missing observations exist during the six months following the equity issue. Further, if the offering firm is de-listed prior to five years following the equity offering, the buy-and-hold returns of the firm and the matching index are truncated at the same time. For equity offerings after 1993, de-listing and buy-and-hold returns are less than five years because the last information gathered in Account Data ends in December 1998. Applying these criteria provides a sample of 142 unseasoned and 413 seasoned equity offerings. Table I provides the distribution of the total sample of IPO stocks and SEO stocks partition by years.

\section{[INSERT TABLE I]}

Table I shows an aggregate issue amount for IPO stocks of 6,604 million $D K K$ and 17,908 million $D K K$ for SEO stocks that yields proceeds of 23,849 million $D K K$ and 46,717 million $D K K$, respectively. We find a large number of equity offerings in the early- and mid-eighties. The samples used in Ritter (1991) and Spiess and AffleckGraves (1995) show similar characteristics. Unseasoned equity offerings experienced a large number of issues particularly in 1984, 1985, and 1986. Table I also shows that the unseasoned offerings are, on average, about as many as seasoned equity offerings in those years, while subsequently there are four to five times as many seasoned as unseasoned equity offerings. The number of SEO stocks is more evenly distributed than IPO stocks over the years 1983 to 1998 varying between 43 offerings in 1986 and 15 offerings in 1987. Of the 413 SEO stocks represented in our sample 242 firms made equity offerings more than once during the sample period. ${ }^{14} \mathrm{~A}$ total of 224 firms of the

\footnotetext{
${ }^{13}$ Account Data is a database that contains information about all firms that are listed on the Copenhagen Stock Exchange. It contains annual reports and market information about each firm/security.

${ }^{14} 107$ firms made two, 61 made three issues; and 34 made four issues, 19 made five issues, 11 made six issues, 5 made seven issues, 3 made eight issues, 2 made nine issues.
} 
sample did not make a second equity issue within a five-year post-offering period. Loughran and Ritter (1995) argue that the under performance in periods with few unseasoned equity offerings is modest, therefore, we partition the sample in sub periods of hot-issue periods and cold-issue periods to confirm whether or not this is evident in our sample. Likewise, we partition the sample by capitalization in order to identify whether under performance is concentrated around small capitalization offers.

To measure the long-run return of an equity offering stock, we calculate the buy-andhold return from the first day of trading over a period of 60 months. Two benchmark returns of the post-offering period are considered: market-adjusted returns and marketmodel returns. To estimate the market-model returns, we use the post-offering period as the estimation window. ${ }^{15}$ The reason is that the seasoned equity offerings typically experience large pre-issue increases in stock prices and stable prices in the post-issue period (Lee et al., 1996). For the initial-public offering stocks, the lack of pre-event returns necessitates a post-offering estimation window of the market-model returns.

\section{Long-Run Security Performance}

Table II shows the average buy-and-hold returns of unseasoned (panel A) and seasoned (panel B) equity offerings using cross-sectional averages, wealth relatives, and transformed buy-and-hold returns. ${ }^{16}$ The average cross-sectional buy-and-hold returns show that the unseasoned and seasoned equity offerings constantly under perform the market when the benchmark is the market-adjusted return. Similar results are documented in Spiess and Affleck-Graves (1995) using average cumulative returns that are adjusted for size, industry and size, and book-to-market and size.

\section{[INSERT TABLE II]}

\footnotetext{
${ }^{15}$ Estimating parameters prior to SEO stocks, as an alternative, provides results (not reported) that are similar to those of the using post parameters.

${ }^{16}$ Ritter (1991) argues that the use of equally weighted monthly returns imply an increasing investment in poorly performing firms is avoided using independent monthly rebalancing. However, the long-run returns using this technique may be downwards biased. In addition, Lee et al. (1996) argue that this rebalancing assumption is in conflict with the problem concerning calendar time intervals, i.e. it is not possible to create a feasible investment strategy.
} 
The results in table II need to be interpreted with caution because the distribution properties of the buy-and-hold returns are unknown. Therefore, it is important to investigate the distribution properties of buy-and-hold returns. The cross-sectional standard deviations are not sufficient statistics if the buy-and-hold returns are not symmetric distributed around the averages. Panel A shows that the average cross-sectional buy-and-hold return after 60 months is 2.5 percent for IPO stocks and 15.8 percent for the market index. After the first 12 months the IPO stocks outperform the market by 7.75 percent $\left(\frac{1.057}{0.981}-1\right)$ while after 60 months the IPO firms under perform the market by 11.5 percent $\left(\frac{1.025}{1.158}-1\right)$. This under performance is of the same magnitude as the findings in Spiess and Affleck-Graves (1995) and Loughran and Ritter (1995) using data from the United States. The 60 months buy-and-hold return from wealth relatives defined as the IPO stocks relative to the market return is negative 27.3 percent. However, for the revised wealth relative (the wealth relative of the market against the IPO stocks) the average buy-and-hold return is 152.6 percent. For the market model, the average transformed buy-and-hold abnormal return $(T-B H A R)$ is negative 21.4 percent and negative 21.3 percent using abnormal returns $r_{i t}-\left(\alpha+\beta \cdot r_{m t}\right)$ and $\left(\alpha+\beta \cdot r_{m t}\right)-r_{i t}$, respectively. Panel B shows that the average buy-and-hold return after 60 months is 6.1 percent for SEO stocks and 40.4 percent for the market index. The SEO stocks constantly under perform the market, e.g. after the first 12 months the SEO firms under perform the market by 5.4 percent and after 60 months the under performance is 22.3 percent. The 60 months buy-and-hold return from the wealth relative defined as the SEO stocks against the market return is negative 21.4 percent. However, for the 1evised wealth relative (the wealth relative of the market against the SEO stocks) the average buy-and-hold return is 128.4 percent. The average transformed buy-and-hold abnormal return $(T-B H A R)$ is negative 18.9 percent and negative 17.6 percent using abnormal returns $r_{i t}-\left(\alpha+\beta \cdot r_{m t}\right)$ and $\left(\alpha+\beta \cdot r_{m t}\right)-r_{i t}$, respectively. The results in table II shows that the expected mean buy-and-hold return depends on the method used to calculate the long-run returns. Overall, the results show that the buy-and-hold returns of the market vary less than the buy-and-hold returns of the IPO and SEO stocks. The buy-and-hold returns that are reported in table II are not applicable for testing the longrun performance of IPO and SEO stocks. 


\section{Results with Log-Normal Transformation}

The differences in the average buy-and-hold return for the market-to-equity wealth relative and the equity-to-market wealth relative are due to the volatility component. Figure 1, panel $\mathrm{A}$ and panel $\mathrm{C}$ show the development in the expected mean buy-andhold return of wealth relatives shown as the normalized measure: $e^{\mu_{J, T} \cdot T}-1$. (Table III summaries results for selected years.) Figure 1, panel B and panel D show the decomposition of the expected mean buy-and-hold return into the normalized transformed mean component, $e^{\alpha_{J, T} \cdot T}-1$ and the normalized volatility component, $e^{1 / 2 \sigma_{J}^{2} \cdot T}-1$, where $J$ $=\{i-m, m-i\}, i=\{I P O$ stocks, SEO stocks $\}$ and $T=\{1, \ldots, 60\}$.

\section{[INSERT FIGURE 1]}

Figure 1 illustrates that it is not possible to draw inference only based on expected mean buy-and-hold returns (panel A and panel C). A total of 10 percent of the IPO stocks' cross-sectional buy-and-hold returns are rejected as being log-normally distributed at a 5 percent level of significance, while 19 percent of the SEO stocks' crosssectional buy-and-hold returns are rejected as being log-normally distributed at a 5 percent level of significance. ${ }^{17}$ Figure 1A provides the expected cross-sectional buyand-hold returns and the decomposition of the wealth relatives related to the IPO stocks. Panel A and panel B in figure 1A shows the results of the IPO-to-market wealth relative. Panel A shows that the IPO stocks under perform relative to the market by 22.9 percent after five years. Using the volatility-adjusted performance measure (panel B), the IPO stocks under perform relative to the market by 43.7 percent after five years. Using the market-to-IPO wealth relative (panel C), the market out performs the IPO stocks by 142.9 percent. The difference between the result in table II and figure 1 arises from the transformation of the buy-and-hold returns into log-normality. The ratio of the two wealth relatives (142.9 to 152.6) expresses the accuracy of the

\footnotetext{
17 The test statistics are based on Doornik and Hansen (1994) that adjust for sample size. The problem is severe for the market model's estimates of buy-and-hold returns while the buy-and-hold returns of wealth relatives are acceptable log-normally distributed. Figures summarizing the probability level of normality and corresponding chi-squared statistics for wealth relatives in the spirit of Loughran and Ritter (1995) are shown in appendix C. Test statistics for distribution properties from the transformed buy-and-hold abnormal returns are available from the authors.
} 
geometric Brownian motion ability to form an approximation of the average buy-andhold returns. The volatility-adjusted performance of the market-to-IPO wealth relative shows that the market out performs the IPO stocks with 77.5 percent after five years (panel D). Comparing panel B and panel D confirms an identical volatility component for the IPO-to-market wealth relative and the market-to-IPO wealth relative.

Figure 1B provides the expected cross-sectional buy-and-hold returns and the decomposition of the wealth relatives related to the SEO stocks. Panel A and panel B in figure 1B shows the results of the SEO-to-market wealth relative. Panel A in figure $1 \mathrm{~B}$ shows that the SEO stocks under perform relative to the market by 17.8 percent after five years. Panel B shows volatility-adjusted performance measure, the results show that the SEO stocks under perform by 38.1 percent after five years. Panel $\mathrm{C}$ in figure 1B shows the market-to-SEO wealth relative. It shows that the market index out performs SEO stocks by 114.4 percent after five years. Applying the volatility-adjusted performance measure, the market out performs the SEO stocks by 61.5 percent after five years.

A correct inference of the mean buy-and-hold returns is to account for the volatility component in the reported returns. Accounting for the volatility component shows that the mean buy-and-hold returns tend to under-estimate the under performance of equity offerings. For example, for IPO stocks the volatility-adjusted under performance is 43.7 percent compared to the average under performance, as reported in table II, of 27.3 percent. Similarly, for SEO stocks the volatility-adjusted under performance is 38.1 percent compared to an average under performance of 21.4 percent. Overall, figure 1 shows that the transformed mean component and the volatility component either amplify or weaken each other. Therefore, the volatility-adjusted performance depends on whether the transformed mean component is positive or negative. Next, we test the transformed mean component and the volatility component to evaluate whether the under performance or the over performance is significant. 


\section{E. Test of Expected Mean and Volatility Component}

The test statistics are displayed graphically rather than numerically and are shown in figure 2. Figure 2: panel $\mathrm{A}$ and $\mathrm{C}$ show the transformed mean components, and panel $\mathrm{B}$ and D show the volatility components. Tests of the market relative to IPO stocks and SEO stocks show that the transformed mean component of the expected cross-sectional buy-and-hold returns is significantly different from zero at a 5\% level of significance after 15 months and after 5 months, respectively. Figure 2 shows the marginal estimates for transformed mean components and volatility components and their respective 95-percent marginal confidence intervals. Any number out side the confidence intervals are significant against the marginal estimates.

\section{[INSERT FIGURE 2]}

The volatility component always contributes positively to the expected cross-sectional buy-and-hold returns. If the transformed mean component is zero and the volatility is positive, and constant, then the level average will increase with the time horizon. The reason is the positive gains accumulate more than the losses even if the transformed mean component is zero. This is the observed right skewness in the development of the cross-sectional buy-and-hold returns.

\section{F. Categorized into Hot Issue Period versus Cold Issue Period}

The unseasoned and seasoned equity offerings are partitioned by a hot (cold) issue period. For the IPO stocks the hot issue period 1983-1986 is investigated. High initial returns and high volumes characterize hot issue periods, i.e. an IPO stock rises above the offering price gaining a higher than average premium in the aftermarket (see Ibbotson and Jaffe (1975) and Loughran, Ritter and Rydqvist (1994)). IPO stocks on the Copenhagen Stock Exchange show a strong relationship between high initial returns and long-run performance in which high initial returns experience negative long-run returns after 5 years. Table III presents the results of hot issues for the period 19831986 and the cold issues for the period 1987-1993. A similar hot issue period from 1983-1986 is reported in Uhlir (1989) for the German IPO market. 


\section{[INSERT TABLE III]}

Table III besides showing sub-sample periods also displays the different methods of calculating long-run returns. All three methods show that the market outperforms equity offerings after five years for the hot issue period. Method 1, which does not adjust for right-skewness, shows that the market out performs IPO stocks by 172.9 percent, while the volatility-adjusted buy-and-hold return shows an over performance of 99.9 percent (method 3). For the cold issue period, using method 1, the market out performs IPO stocks with 64.6 percent after five years while the volatility-adjusted out performance is 29.3 percent after five years. These reported out performance percentages are numbers that arise when the market is measured relative to the equity issues stocks. However, for the reverse wealth-relative measure (IPO-to-market) using method 1 the under performance in the hot issue period is only 36.4 percent after five years and for the cold issues period the under performance is only 9.0 percent. This may seem odd but it is caused by the fact that the volatility component is identical for the two wealthrelative measures: IPO-to-market and market-to-IPO. Adjusting for the volatility, i.e. using method 3, shows that hot (cold) issue period under perform by 50.0 percent $(22.0$ percent). The measures of volatility-adjusted performance are compatible irrespectively of whether out performance or under performance is considered.

Loughran and Ritter (1995) argue that the under performance in periods with few unseasoned equity offerings are modest which is confirmed in our cold issue period. Hot issue periods experience a more severe long-run under-performance than cold issue periods. Loughran, Ritter and Rydqvist (1994) also document the tendency of high initial returns and volumes after a period of high stock market performance. We investigate whether or not this inverse relationship exists between the one-year return and the five-years return. The results show that the under performance after one year for hot (cold) issue periods is 4.1 percent (5.9 percent) while the under performance after five years for hot (cold) issue periods is 50.0 percent (22.6 percent) using method 3 . Thus, the results may indicate that investors that invest in initial public offerings in cold issue periods are better off in the long run than investors that invest in initial public offerings in a hot issue period. 
All three methods in table III show under performance of the 142 IPO stocks and 413 SEO stocks for the total sample period. Method 3 shows that the IPO stocks and the SEO stocks significantly under perform the market by 43.7 percent and 38.1 percent using the volatility-adjusted performance measure. The results confirm the similarities between IPO stocks and SEO stocks long-run performance and that the IPO stocks under perform more relative to the market than SEO stocks.

\section{G. Categorized by Market Capitalization}

We partition the sample by the size of the equity offerings to investigate whether under performance is concentrated around small capitalization offers. This partition may 1eveal differences in observed long-run returns. Table IV shows the unseasoned equity offerings categorized by market capitalization and seasoned equity offerings categorized by the proceed-to-market value ratio.

\section{[INSERT TABLE IV]}

Panel A provides the results of the post-performance of IPO stocks using all three methods. Comparing the results of method 1 and method 2 provides some evidence that the lowest quartile under performs more than the highest quartile. Method 3 confirms that small capitalization issues under perform relative to large capitalization $\dot{\mathrm{s}}$ sues. The out performance by the market after five years for the highest quartile is not statistically significant at a 5 percent level. This indicates that under performance seems to be concentrated in small capitalization firms. Whereas, only little evidence indicates that the poor long-run performance of IPO stocks is concentrated in small capitalization stocks. In addition, the under performance after one year for three of the quartiles are not statistically significant at any level.

Panel B provides the results of the performance of SEO stocks group by the proceedto-market value ratio. This ratio is chosen to capture the performance of equity offerings relative to existing market value. The result shows that the market outperforms SEO stocks after five years for all quartiles and the out performance is statistically sig- 
nificant at a 1-percent critical level of significance. The sample provides no evidence of different under performance for the market capitalization quartiles. Method 3 shows that the volatility-adjusted buy-and-hold returns after five years vary between 42.3 percent (highest quartile) and 95.0 percent (third quartile). Spiess and Affleck-Graves (1995) find some evidence that smaller firm's experience more severe under performance when partitioning their sample by book-to-market value. We find no such evidence looking at the relative size of the Danish equity offering.

\section{Conclusion}

This paper shows that the volatility-adjusted performance measure is a better measure of long-run returns than just considering a simple arithmetic average. First, we identify transformations of data that exhibit log-normally distributed cross-sectional buy-andhold returns. Secondly, we decompose the expected cross-sectional buy-and-hold returns into transformed mean components and volatility components. For the wealth relative measure, we document that it is necessary to correct the expected crosssectional mean buy-and-hold return for the volatility component. We report that whether accumulated returns are calculated using the market-to-security or the security-to-market wealth relative, the volatility component introduces an identical upward bias. The expected buy-and-hold returns must be adjusted for the volatility component to show coherent security performance.

We investigate the long-run security performance made by 142 IPO stocks and 413 SEO stocks at the Copenhagen Stock Exchange during the period 1983-1998. The results document volatility-adjusted buy-and-hold returns that show that unseasoned and seasoned equity offerings under perform over a five-year period by 43.7 percent and 38.1 percent, respectively. The under performance is more evident for equity offerings in a hot issue period compared to a cold issue period. Moreover, there is little evidence that small capitalization issues under perform relative to large capitalization issues. We document that IPO stocks with large capitalization issues do not under perform in the 
long run. Also, SEO stocks grouped by the proceed-to-market value ratio show no evidence of different under performance for various market capitalization quartiles. 


\section{Appendix A: Transformed Buy-and-Hold Returns}

An alternative measure of long-run abnormal returns denoted by the transformed buyand-hold return $(T-B H A R)$ is:

$$
T-B H A R_{i-m, T}=\prod_{t=1}^{T}\left(1+a r_{t}\right)
$$

where the abnormal return is defined as $a r_{t}=r_{i, t}-r_{m, t}$. The usual measurement of crosssectional buy-and-hold return is defined $B H A R_{-m, T}=\left(\prod_{t=1}^{T}\left(1+r_{i, t}\right)-\prod_{t=1}^{T}\left(1+r_{m, t}\right)\right)$. The average cross-sectional T-BHAR is:

$$
\overline{T-B H A R}_{i-m, T}=\frac{1}{N} \sum_{i=1}^{N}\left(\prod_{t=1}^{T}\left(1+a r_{t}^{i-m}\right)\right)=\frac{1}{N} \sum_{i=1}^{N}\left(e^{\sum_{t=1}^{T} \log \left(1+a r_{t}^{i-m}\right)}\right)
$$

Applying a geometric Brownian motion in continuous times:

$$
d \log T-B H A R=\mu_{a r} d t+\sigma_{a r} d z_{t}
$$

where

$$
T-B H A R_{i-m, T}=e^{\mu_{a r} T+\sigma_{a r} z_{T}}
$$

where $z_{T} \sim N(0, T)$. A serious problem arises when applying (A.4) if the abnormal return $a r_{t}$ at any time is less than minus 1 because the logarithm cannot be taken on $\left(1+a r_{t}\right)$. An explicit structure of the geometric Brownian motion can be enforced on the BHAR. But, BHAR consists of a difference between two exponential expressions. Therefore, it does not assist in separating the mean component from the volatility component. Empirically, the various combinations $T-B H A R_{i-m, T}$ and $T-B H A R_{m-i, T}$ are equivalent to the wealth relatives with the only difference being the sizes of the numbers. 


\section{Appendix B: Decomposing Expected Mean Buy-and-Hold Returns}

Define a wealth relative at time $T$ by the variable $W_{T}$. If the logarithm of the wealth relative at time $T$ is normally distributed with transformed mean $\alpha_{T} \cdot T$ and variance $\sigma_{T}^{2} \cdot T$ :

$$
\log \left(W_{T}\right) \sim N\left(\alpha_{T} \cdot T ; \sigma_{T}^{2} \cdot \sqrt{T}\right)
$$

then the wealth relative, $W_{T}$, is log-normally distributed: $W_{T}=e^{\log \left(W_{T}\right)}$. As $W_{T}$ is $\log$ normally distributed the expected mean of the wealth relative is given by:

$$
\begin{aligned}
E\left(W_{T}\right)= & e^{\mu_{T} \cdot T}=e^{\alpha_{T} \cdot T+\frac{1}{2} \sigma_{T}^{2} \cdot T} \\
& =\underbrace{e_{\text {Volatility }}^{\alpha_{T} \cdot T}}_{\begin{array}{c}
\text { Transformed } \\
\text { mean component }
\end{array}} \cdot \underbrace{e^{\frac{1}{2} \sigma_{T}^{2} \cdot T}}_{\text {component }}
\end{aligned}
$$

where the definition $\mu_{T} \equiv \alpha_{T}+\frac{1}{2} \sigma_{T}^{2}$ is used. The variance of $W_{T}$ is given by:

$$
\begin{aligned}
& \operatorname{Var}\left(W_{T}\right)=e^{\left(2 \mu_{T}+\sigma_{T}^{2}\right) \cdot T} \cdot\left(e^{\sigma_{T}^{2} \cdot T}-1\right) \\
& =e^{\left(2 \cdot\left(\alpha_{T}+\frac{1}{2} \sigma_{T}^{2}\right)+\sigma_{T}^{2}\right) \cdot T} \cdot\left(e^{\sigma_{T}^{2} \cdot T}-1\right)
\end{aligned}
$$

Using the structure of a geometric Brownian motion with the dynamics $d W_{t}=\mu_{t} W_{t} d t+\sigma_{t} W_{t} d Z_{t}$ and applying Ito's lemma on $\log \left(W_{T}\right)$ :

$$
\begin{aligned}
d \log \left(W_{t}\right) & =\frac{\partial \log \left(W_{t}\right)}{\partial t} d t+\frac{\partial \log \left(W_{t}\right)}{\partial W_{t}} d W_{t}+\frac{1}{2} \cdot \frac{\partial^{2} \log \left(W_{t}\right)}{\partial W_{t}^{2}}\left(d W_{t}\right)^{2} d t \\
& =\mu_{t} d t \cdot+\sigma_{t} Z_{t}-\frac{1}{2} \sigma_{t}^{2} d t \\
& =\left(\mu_{t}-\frac{1}{2} \sigma_{t}^{2}\right) d t+\sigma_{t} Z_{t}
\end{aligned}
$$


where $\frac{\partial \log \left(W_{T}\right)}{\partial t}=0, \frac{\partial \log \left(W_{T}\right)}{\partial W_{T}}=\frac{1}{W_{T}}, \frac{\partial^{2} \log \left(W_{T}\right)}{\partial W_{T}^{2}}=-\frac{1}{W_{T}^{2}}$

This provides the mean component and the volatility component:

$$
\begin{aligned}
& W_{T}=W_{0}+\int_{0}^{T} \mu_{t} W_{t} d t+\int_{0}^{T} \sigma_{t} W_{t} d Z_{t} \\
& W_{T}=e^{\left(\mu_{T}-\frac{1}{2} \sigma_{T}^{2}\right) \cdot T+\sigma_{T} \cdot Z_{T}}
\end{aligned}
$$

where $\mu_{T} \equiv \alpha_{T}+\frac{1}{2} \sigma_{T}^{2}$ is the drift and $\alpha_{T}$ and $\sigma_{T}^{2}$ are the marginal parameter estimates an any point in time. At time $T$ the transformed mean component and the volatility component of $\log \left(W_{T}\right)$ is $\alpha_{T} \cdot$ Tand $\sigma_{T}^{2} \cdot \sqrt{T}$. 


\section{Appendix C Test Statistics for Normality}

The test statistics that adjusts for sample size are based on Doornik \& Hansen (1994). Panel A and B summarize the probability level of normality and corresponding chi-squared statistics for wealth relatives in the spirit of Ritter (1991) and Loughran \& Ritter (1995). The horizontal line shows the 5 percent level of significance for being log-normally distributed.

Panel A Chi-squared of normality for wealth relatives of IPO's

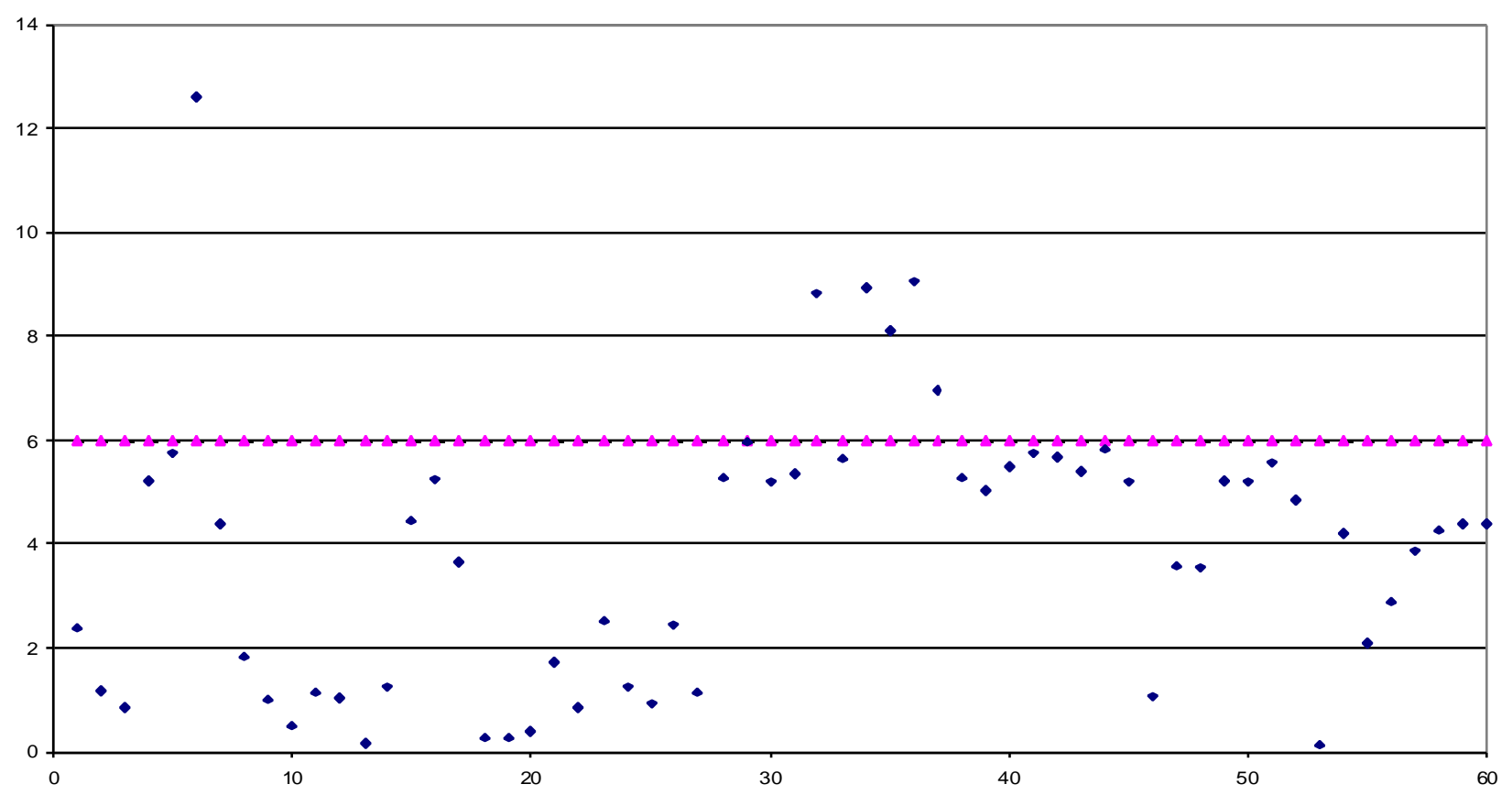

Panel B Chi-squared of normality for wealth relatives of SEO's

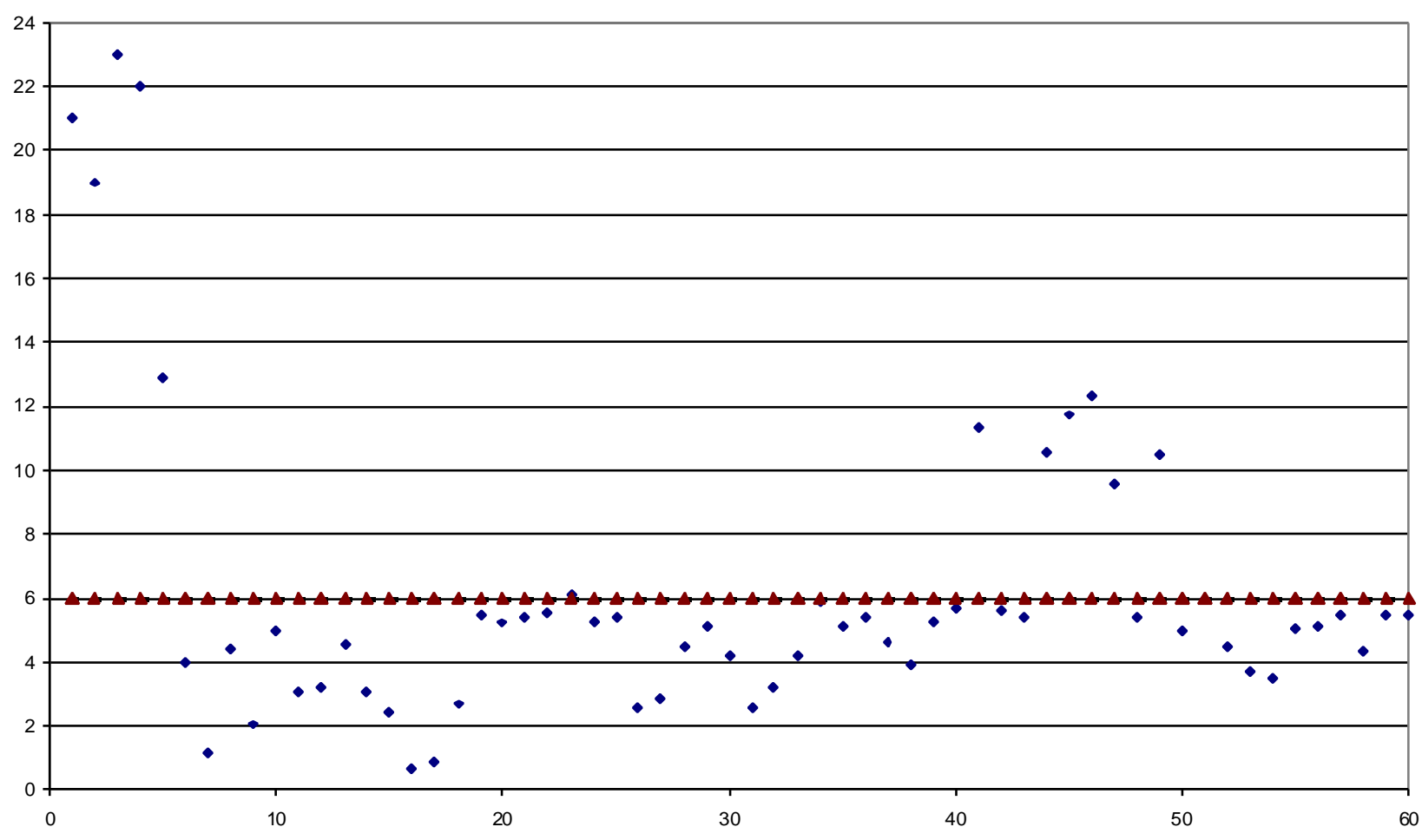




\section{Reference:}

Agrawal, Anup, Jeffrey F. Jaffe, and Gershon N. Mandelker, 1992, The Post-Merger

Performance of Acquiring Firms: A Re-examination of an Anomaly, Journal of Finance 47, 1605-1621

Barber, Brad M. and John D. Lyon, 1997, Detecting long-run abnormal stock returns: The empirical power and specification of test statistics, Journal of Financial Economics 43, 341-372

Barberis, N., Shleifer, A. and R. Vishny, 1998, A model of investor sentiment, Journal of Financial Economics 49, 307-343

Bigelli, Marco, 1997, The quasi-split effect, active insiders and positive abnormal returns in European equity rights issues: evidence from Italy, Unpublished working paper, University of Bologna

Blume, Marshall and Robert F. Stambaugh, 1983, Biases in computed returns: An application to the size effect, Journal of Financial Econometrics 12, 387-404

Brown, S. and J. Warner, 1985, Using Daily Stock Returns: The Case of Event Studies, Journal of Financial Economics 14, 3-31

Bøhren, Øyvind, B. Espen Eckbo and Dag Michalsen, 1997, Why underwrite rights offerings? Some new evidence, Journal of Financial Economics 46, 223-261

Canina, Linda, Roni Michaely, Richard Thaler, and Kent Womack, 1998, Caveat Compunder: A Warning About Using the Daily CRSP Equal-Weighted Index to Compute Long-Run Excess Returns, Journal of Finance 53, 403-416

Cambell, John, Y, Andrew W. Lo, and A. Craig MacKinlay, 1997, The Econometrics of Financial Markets, Princeton University Press

Conrad, J. and G. Kaul, 1993, Long-term market overreaction or biases in computed returns, Journal of Finance 48, 39-63

Cowan, Arnold R. and Anne M. A. Sergeant, 1997, Interacting Biases, Non-Normal Return Distributions and the Performance of Parametric and Bootstrap Tests for Longrun Event Studies, Unpublished working paper, College of Business Iowa State University

Daniel, K., Hirshleifer, D. and A. Subrahmanyam, 1998, A theory of overconfidence, self-attribution, and security market under- and over-reactions, Journal of Finance

Dhatt, M.S., Kim, Y.H., and S. Mukherji, 1996, Seasoned equity issues: the Korean experience, Pacific-Basin Finance Journal (4)1, 31-43

Doornik, J.A. and H. Hansen (1994), An Omnibus Test for Univariate And Multivariate Normality, Unpublished working paper, Nuffield College, Oxford. 
Dubois, M. and P. Jeannenret, 1998, The Long-Run Performance of Seasoned Equity offerings with Rights, Unpublished working paper, University of Neuchâtel

Eckbo, B.E., and R.W. Masulis, 1995, Seasoned equity offerings: a survey. Jarrow et al., Finance, Handbooks in Operations Research and Management Science. Vol.9 North-Holland, Amsterdam, pp. 1017-1072

Fama, Eugene F., 1998, Market efficiency, long-run returns, and behavioral finance, Journal of Financial Economics 49, 283-306

Hietala, P. and T. Löyttyniemi, 1991, Raising equity using rights issues: evidence on signalling, Unpublished working paper, INSEAD, Fontainebleu, France Ibbotson Roger G. \& Jeffrey F. Jaffe, 1975, "Hot Issues" Markets, Journal of Finance $30,1027-1042$

Ibbotson Roger G., and Jay R. Ritter, 1995, Seasoned equity offerings: a survey. Jarrow et al., Finance, Handbooks in Operations Research and Management Science. Vol. 9 North-Holland, Amsterdam, pp. 993-1016

Ikenberry, David, Josef Lakonishok, and Theo Vermaelen, 1995, Does the stock market overreact?, Journal of Finance 40, 793-805

Jakobsen, Jan and Ole Sørensen, 1999, Decomposing and testing long-run returns: with an application to initial public offerings in Denmark, Unpublished working paper, Copenhagen Business School, Copenhagen

Kang, J., and R. Stulz, 1996, How different are Japanese corporate finance? An investigation of new security issues, Review of Financials Studies 9, 109-139

Kelharju, M., 1993, The Winner's Curse, Legal Liability, and Long-Run Price Performance of Initial Public Offerings in Finland, Journal of Financial Economics 18, 705-723

Kothari, S. P. and Jerold B. Warner, 1997, Measuring long-run security price performance, Journal of Financial Economics 43, 301-339

Kunz, R.M., and R. Aggarwal, 1994, Why Initial Public Offerings are Under Priced: Evidence From Switzerland, Journal of Banking and Finance 20, 1189-1210

Lee, Philip J. Stephen L. Taylor and Terry S. Walter, 1996, Australian IPO pricing in the short and long run, Journal of Banking and Finance 20, 1189-1210

Lo, Andrew, and Craig MacKinlay, 1990, When are contrarian profits due to stock market overreaction? Review of Financial Studies 3. 175-205

Loderer, C.F. and H. Zimmermann, 1988, Stock offerings in a different setting: The Swiss case 1973-1983, Journal of Banking and Finance, 353-378 
Loughran, T. and A. Vijh, 1997, Do long-run shareholders benefit from corporate takeovers?, Journal of Finance 52, 176-1790

Loughran, T. and Jay R. Ritter, 1995, The New Issues Puzzle, Journal of Finance 50, $23-50$

Lyon, John D., Brad M. Barber and Chih-Ling Tsai, 1999, Improved Methods for Tests of Long-Run Abnormal Returns, Journal of Finance 54, 165-201

Page, M.J., and I. Reyneke, 1997, The Timing and Subsequent Performance of Initial Public Offerings on The Johannesburg Stock Exchange, Journal of Business Finance and Accounting 24, 1401-1420

Smith, Clifford, W. Jr., 1986, Investment banking and the capital acquisition process, Journal of Financial Economics 15, 3-29

Tsangarakis, N. V., 1996, Shareholder wealth effects of equity issues in emerging markets: Evidence from rights offerings in Greece, Financial Management 25, 21-32

Uhlir, H., 1989, A Reappraisal of the Efficiency of Financial Markets, Going public in the F.R.G., in: R. Guimaras et al (eds.), Springer-Verlag, Berlin 
Table I Distribution of Equity Offerings on the Copenhagen Stock Exchange

We construct the sample by gathering information of unseasoned and seasoned equity offerings during the period 1983-1998. The data source is Account Data for identifying security offerings and offerings characteristics. The total sample consists of all equity offerings on the Copenhagen Stock Exchange. For an equity offering to be included in the sample it must meet the following three criteria: 1) the issue must be a primary offering, i.e. offerings that include secondary shares are excluded; 2) joint offerings are excluded; and 3) the offering firm must be listed on the Account Data's database of security price information at the time of the issue. In addition, we evaluate the pricing information to identify and exclude any equity offerings in which missing observations exists during the six months following the offering. Offering is the nominal equity issue and proceed is the market capitalization of the issue.

\begin{tabular}{|c|c|c|c|c|c|c|}
\hline \multirow[b]{2}{*}{ Year } & \multicolumn{3}{|c|}{ Unseasoned Equity Offerings } & \multicolumn{3}{|c|}{ Seasoned Equity Offerings } \\
\hline & Number & Offering $^{a}$ & Proceed $^{\mathrm{a}}$ & Number & Offering $^{\mathrm{a}}$ & Proceed $^{\mathrm{a}}$ \\
\hline 1983 & 7 & 63 & 220 & 24 & 533 & 779 \\
\hline 1984 & 23 & 298 & 786 & 27 & 893 & 1,731 \\
\hline 1985 & 12 & 547 & 3,882 & 25 & 955 & 1,603 \\
\hline 1986 & 23 & 381 & 845 & 43 & 1,389 & 3,453 \\
\hline 1987 & 4 & 21 & 59 & 15 & 619 & 1,353 \\
\hline 1988 & 3 & 252 & 325 & 24 & 364 & 1,283 \\
\hline 1989 & 9 & 1,160 & 1,276 & 32 & 1,280 & 3,727 \\
\hline 1990 & 12 & 731 & 1,582 & 24 & 1,123 & 3,579 \\
\hline 1991 & 8 & 682 & 1,646 & 31 & 2,674 & 10,258 \\
\hline 1992 & 4 & 257 & 292 & 27 & 2,639 & 4,569 \\
\hline 1993 & 4 & 503 & 1,732 & 16 & 159 & 287 \\
\hline 1994 & 6 & 1,152 & 3,007 & 26 & 2,517 & 6,112 \\
\hline 1995 & 10 & 207 & 2,344 & 27 & 613 & 2,164 \\
\hline 1996 & 6 & 273 & 4,778 & 23 & 1,122 & 2,167 \\
\hline 1997 & 4 & 17 & 234 & 33 & 753 & 2,808 \\
\hline 1998 & 7 & 59 & 840 & 16 & 276 & 846 \\
\hline Total & 142 & 6,604 & 23,849 & 413 & 17,908 & 46,717 \\
\hline
\end{tabular}

${ }^{a}$ Amount issued and proceeds in million DKK. 
Table II Long-Run Returns for Unseasoned and Seasoned Equity Offerings

The time horizon is shown in the first column. The buy-and-hold returns are calculated assuming that an investor invests in an equally weighted portfolio of firms at the day of the equity offering. The wealth relatives are used to calculate buy-and-hold returns, $W_{i, t}=W_{0, t} \cdot \prod_{i=1}^{T}\left(1+r_{i, t}\right)$. Applied wealth relatives are market-to-equity offering $\left(W_{m, T} / W_{i, T}\right)$ and equity offering-to-market $\left(W_{i, T} / W_{m, T}\right)$, respectively. Two versions of the market model are applied, the standard method where the abnormal return (1) is $M A R_{i t}=r_{i t}-\left(\alpha+\beta \cdot r_{m t}\right)$, but also by subtracting the firm-specific return from the market return (2) $M A R_{i t}=\left(\alpha+\beta \cdot r_{m t}\right)-r_{i t} \cdot$ The $M A R_{i t}$ is used to calculate the transformed buy-and-hold abnormal return (T-BHAR). Standard deviations are shown in parentheses.

\section{Panel A: Unseasoned Equity Offerings}

\begin{tabular}{|c|c|c|c|c|c|c|c|}
\hline \multirow{2}{*}{ Months } & \multirow{2}{*}{$\mathrm{N}$} & IPO's & Market & \multicolumn{2}{|c|}{ Wealth Relatives } & \multicolumn{2}{|c|}{$T-B H A R$} \\
\hline & & $W_{i, t}-1$ & $W_{m, t^{-}}-1$ & $\left(W_{m, T} / W_{i, T}\right)-1$ & $\left(W_{i, T} / W_{m, T}\right)-1$ & $\prod^{T}\left(M A R_{m-i, t}\right)^{-1}$ & $\prod^{T}\left(M_{1} A R_{i-m, t}\right)^{-1}$ \\
\hline \multirow[t]{2}{*}{12} & 142 & 0.057 & -0.019 & 0.121 & 0.002 & 0.063 & -0.062 \\
\hline & & $(0.44)$ & $(0.18)$ & $(0.45)$ & $(0.36)$ & $(0.31)$ & $(0.28)$ \\
\hline \multirow[t]{2}{*}{24} & 142 & 0.089 & 0.013 & 0.335 & -0.024 & 0.075 & -0.097 \\
\hline & & $(0.69)$ & $(0.27)$ & $(0.83)$ & $(0.52)$ & $(0.46)$ & $(0.33)$ \\
\hline \multirow[t]{2}{*}{36} & 142 & 0.025 & 0.034 & 1.008 & -0.157 & -0.051 & -0.106 \\
\hline & & $(0.88)$ & $(0.32)$ & (1.99) & (0.58) & $(0.41)$ & (0.39) \\
\hline \multirow[t]{2}{*}{48} & 142 & 0.013 & 0.129 & 1.133 & -0.201 & -0.113 & -0.169 \\
\hline & & $(0.78)$ & $(0.32)$ & $(2.57)$ & $(0.56)$ & $(0.34)$ & $(0.24)$ \\
\hline \multirow[t]{2}{*}{60} & 142 & 0.025 & 0.158 & 1.526 & -0.273 & -0.213 & -0.214 \\
\hline & & $(0.81)$ & $(0.36)$ & (2.89) & $(0.53)$ & $(0.14)$ & $(0.15)$ \\
\hline
\end{tabular}

Panel B: Seasoned Equity Offerings

\begin{tabular}{|c|c|c|c|c|c|c|c|}
\hline \multirow{2}{*}{ Months } & \multirow{2}{*}{$\mathrm{N}$} & SEO's & Market & \multicolumn{2}{|c|}{ Wealth Relatives } & \multicolumn{2}{|c|}{$T-B H A R$} \\
\hline & & $W_{i, t}-1$ & $W_{m, t^{-}}-1$ & $\left(W_{m, T} / W_{i, T}\right)-1$ & $\left(W_{i, T} / W_{m, T}\right)-1$ & $\prod^{T}\left(M_{A R_{m-i, t}}\right)^{-1}$ & $\prod^{T}\left(M A R_{i-m, t}\right)^{-1}$ \\
\hline \multirow[t]{2}{*}{12} & 413 & 0.019 & 0.077 & 0.161 & -0.038 & 0.039 & -0.052 \\
\hline & & $(0.35)$ & $(0.21)$ & (0.49) & $(0.32)$ & $(0.28)$ & $(0.27)$ \\
\hline \multirow[t]{2}{*}{24} & 413 & 0.051 & 0.163 & 0.404 & -0.069 & 0.032 & -0.075 \\
\hline & & $(0.51)$ & (0.29) & (1.07) & $(0.46)$ & $(0.36)$ & $(0.34)$ \\
\hline \multirow[t]{2}{*}{36} & 413 & 0.065 & 0.253 & 0.621 & -0.121 & -0.013 & -0.109 \\
\hline & & $(0.59)$ & (0.34) & (1.31) & $(0.50)$ & $(0.36)$ & (0.33) \\
\hline \multirow[t]{2}{*}{48} & 413 & 0.060 & 0.253 & 0.781 & -0.157 & -0.066 & -0.175 \\
\hline & & $(0.60)$ & $(0.35)$ & (1.64) & $(0.49)$ & $(0.30)$ & $(0.24)$ \\
\hline \multirow[t]{2}{*}{60} & 413 & 0.061 & 0.404 & 1.284 & -0.214 & -0.176 & -0.189 \\
\hline & & $(0.69)$ & $(0.38)$ & $(3.16)$ & $(0.55)$ & $(0.15)$ & $(0.15)$ \\
\hline
\end{tabular}


Table III Test of Long-Run Returns for Unseasoned Equity Hot and Cold Issues and Seasoned Equity Offerings

The unseasoned equity offerings are partitioned into a hot issue group from 1983-1986 and a cold issue group from 1987-1993. The period 1983-1998 long run returns for all IPO's and SEO's are reported. Method 1 is a simple arithmetic average calculation after $T$ years, which does not adjust for right skewness. Applied wealth relatives are market-to-equity offering $\left(W_{m, T} / W_{i, T}\right)$ and equity offering-to-market $\left(W_{i, T} / W_{m, T}\right)$, respectively. Method 2 describes the buyand-hold returns with expected mean of $e^{\left(\alpha_{T}+\frac{1}{2} \sigma_{T}^{2}\right)_{T}}$. The method includes the problem of testing the cross-sectional average buy-and-hold returns in levels. Method 3 transforms the wealth relatives to logarithms and tests the transformed mean component and the volatility component. The reported figure is $e^{\alpha_{T} \cdot T}-1$ while the volatility component, $e^{1 / 2 \sigma_{T}^{2} \cdot T}-1$, is filtered out. The volatility is shown in $\{\cdot\}$. Standard deviations are provided in (.) for method 1 and 2. The time horizon $(T)$ is 1 year, 3 years, and 5 years after the first day of trading.

\begin{tabular}{|c|c|c|c|c|c|c|c|c|c|c|c|c|c|}
\hline \multirow[b]{3}{*}{ Test } & \multirow[b]{3}{*}{$\begin{array}{l}\text { Wealth } \\
\text { Relative }\end{array}$} & \multirow[b]{3}{*}{1 year } & \multicolumn{7}{|c|}{ Unseasoned Equity Offerings } & \multirow[b]{3}{*}{5 years } & \multirow{2}{*}{\multicolumn{3}{|c|}{$\begin{array}{c}\text { Seasoned Equity Offerings } \\
\text { Period } \\
1983-1998\end{array}$}} \\
\hline & & & \multicolumn{2}{|c|}{$\begin{array}{c}\text { Hot Issue } \\
1983-1986\end{array}$} & \multicolumn{3}{|c|}{$\begin{array}{c}\text { Cold Issue } \\
1987-1993\end{array}$} & \multicolumn{2}{|r|}{$\begin{array}{c}\text { Period } \\
1983-1998\end{array}$} & & & & \\
\hline & & & $\begin{array}{c}\mathrm{N}=65 \\
3 \text { years }\end{array}$ & 5 years & 1 year & $\begin{array}{c}\mathrm{N}=44 \\
3 \text { years }\end{array}$ & 5 years & 1 year & $\begin{array}{l}\mathrm{N}=142 \\
3 \text { years }\end{array}$ & & 1 year & $\begin{array}{l}\mathrm{N}=413 \\
3 \text { years }\end{array}$ & 5 years \\
\hline \multirow[t]{4}{*}{ Method 1} & $\left(W_{m, T} / W_{i, T}\right)$ & 10.68 & 76.44 & 172.88 & 11.13 & 105.83 & 64.56 & 12.14 & 100.79 & 152.56 & 16.06 & 62.09 & 128.35 \\
\hline & & (49.59) & (123.18) & (293.64) & $(43.28)$ & (274.10) & $(177.41)$ & (44.97) & (198.83) & $(289.11)$ & $(49.26)$ & (131.08) & $(315.89)$ \\
\hline & $\left(W_{i, T} / W_{m, T}\right)$ & 1.01 & -15.85 & -36.43 & -1.76 & -12.16 & -9.03 & -0.21 & -15.76 & -27.29 & -3.85 & -12.09 & -21.36 \\
\hline & & $(37.57)$ & (63.97) & (49.27) & (37.63) & (53.60) & $(56.46)$ & $(36.21)$ & $(57.50)$ & $(53.50)$ & (31.98) & (49.57) & $(54.51)$ \\
\hline \multirow[t]{4}{*}{ Method 2} & $\left(W_{m, T} / W_{i, T}\right)$ & 11.86 & 79.88 & 167.14 & 13.82 & 87.21 & 63.81 & 12.74 & 95.09 & 142.88 & 15.71 & 59.09 & 114.44 \\
\hline & & $(43.56)$ & $(131.74)$ & $(236.80)$ & $(43.60)$ & (175.20) & $(127.50)$ & $(42.33)$ & (165.58) & (226.99) & $(39.82)$ & $(103.91)$ & $(187.24)$ \\
\hline & $\left(W_{i, T} / W_{m, T}\right)$ & 2.95 & -14.59 & -33.15 & 0.75 & 0.19 & -1.97 & 1.19 & -11.82 & -22.86 & -3.34 & -10.32 & -17.81 \\
\hline & & (40.09) & $(62.55)$ & (59.26) & $(38.60)$ & (93.76) & (76.29) & (37.98) & (74.84) & (72.09) & $(39.81)$ & (103.913) & (187.24) \\
\hline \multirow[t]{4}{*}{ Method 3} & $\left(W_{m, T} / W_{i, T}\right)$ & 4.24 & $45.12^{\mathrm{a}}$ & $99.90^{\mathrm{a}}$ & 6.29 & $36.69^{\mathrm{b}}$ & $29.27^{\mathrm{b}}$ & $5.55^{\mathrm{b}}$ & $48.74^{\mathrm{a}}$ & $77.45^{\mathrm{a}}$ & $9.41^{\mathrm{a}}$ & $33.18^{\mathrm{a}}$ & $61.53^{\mathrm{a}}$ \\
\hline & & $\{0.19\}$ & $\{23.95\}$ & $\{33.63\}$ & $\{7.09\}$ & $\{36.96\}$ & $\{26.72\}$ & $\{6.81\}$ & $\{31.16\}$ & $\{36.87\}$ & $\{5.76\}^{\mathrm{a}}$ & $\{19.44\}$ & $\{32.75\}$ \\
\hline & $\left(W_{i, T} / W_{m, T}\right)$ & -4.07 & -31.09 & $-49.98^{\mathrm{a}}$ & -5.92 & $-26.84^{\mathrm{b}}$ & $-22.64^{\mathrm{b}}$ & $-5.25^{\mathrm{a}}$ & $-32.77^{a}$ & $-43.65^{\mathrm{a}}$ & $-8.60^{\mathrm{a}}$ & $-24.91^{\mathrm{a}}$ & $-38.09^{a}$ \\
\hline & & $\{0.19\}$ & $\{23.95\}$ & $\{33.63\}^{\mathrm{a}}$ & $\{7.09\}$ & $\{36.96\}$ & $\{26.72\}$ & $\{6.81\}$ & $\{31.16\}$ & $\{36.87\}$ & $\{5.76\}$ & $\{19.44\}$ & $\{32.75\}$ \\
\hline
\end{tabular}

$\overline{\mathrm{a}, \mathrm{b}}$ Statistical significance at $1 \%$ and $5 \%$ level, respectively. 


\section{Table IV IPO's and SEO's Partition Market Capitalization Quartiles}

The market capitalization for IPO's is used to generate four quartiles. The ratio of market capitalization of proceeds to the market value is used to generate four quartiles for SEO's. Method 1 is a simple arithmetic average calculation after $\mathrm{T}$ years, which does not adjust for right skewness. The applied wealth relative is market-to-equity offering $\left(W_{m, T} / W_{i, T}\right)$. Method 2 describes the buy-and-hold returns with the expected value $e^{\left(\alpha_{T}+1 / 2 \sigma^{2}\right)_{T} T}$. Method 3 transforms the wealth relatives to logarithms and tests the transformed mean component and the volatility component. The reported figure is $e^{\alpha_{T} \cdot T}-1$ while the volatility component, $e^{1 / 2 \sigma_{T}^{2} \cdot T}-1$, is filtered out. Standard deviations are provided in $(\cdot)$ for method 1 and 2 . The probability (p-values) of values being equal to zero are provided in $\{\cdot\}$. The time horizon $(T)$ is 1 year, 3 years, and 5 years after the first day of trading.

\section{Panel A: Unseasoned Equity Offerings}

\begin{tabular}{cccccccccc} 
& \multicolumn{3}{c}{ Method 1 } & \multicolumn{3}{c}{ Method 2 } & \multicolumn{3}{c}{ Method 3 } \\
Quartile & 1 year & 3 years & 5 years & 1 year & 3 years & 5 years & 1 year & 3 years & 5 years \\
\hline Lowest & 4.14 & 91.61 & 165.38 & 7.21 & 94.23 & 151.21 & 0.18 & 44.63 & 79.26 \\
& $(43.92)$ & $(178.84)$ & $(364.08)$ & $(40.85)$ & $(174.10)$ & $(246.63)$ & $\{0.49\}$ & $\{0.01\}^{\mathrm{a}}$ & $\{0.00\}^{\mathrm{a}}$ \\
2 & 8.91 & 72.24 & 162.70 & 10.98 & 75.37 & 161.52 & 3.63 & 42.83 & 115.25 \\
& $(52.45)$ & $(125.56)$ & $(237.25)$ & $(42.57)$ & $(124.96)$ & $(180.45)$ & $\{0.29\}$ & $\{0.00\}^{\mathrm{a}}$ & $\{0.00\}^{\mathrm{a}}$ \\
3 & 15.56 & 155.74 & 51.70 & 21.55 & 149.59 & 65.05 & 13.94 & 74.42 & 41.87 \\
& $(42.73)$ & $(313.83)$ & $(98.99)$ & $(45.16)$ & $(255.47)$ & $(98.13)$ & $\{0.03\}^{\mathrm{b}}$ & $\{0.00\}^{\mathrm{a}}$ & $\{0.00\}^{\mathrm{a}}$ \\
\multirow{3}{*}{ Highest } & 4.25 & 42.96 & 126.93 & 10.18 & 61.09 & 146.74 & 3.03 & 30.91 & 48.63 \\
& $(40.01)$ & $(102.59)$ & $(257.29)$ & $(41.76)$ & $(115.51)$ & $(326.94)$ & $\{0.33\}$ & $\{0.03\}^{\mathrm{b}}$ & $\{0.06\}$ \\
\hline
\end{tabular}

\section{Panel B: Seasoned Equity Offerings}

\begin{tabular}{cccccccccc} 
& \multicolumn{3}{c}{ Method 1 } & \multicolumn{3}{c}{ Method 2 } & \multicolumn{3}{c}{ Method 3 } \\
Quartile & 1 year & 3 years & 5 years & 1 year & 3 years & 5 years & 1 year & 3 years & 5 years \\
\hline Lowest & 16.01 & 47.18 & 101.58 & 16.63 & 45.48 & 102.29 & 10.91 & 21.44 & 55.60 \\
& $(43.92)$ & $(130.56)$ & $(175.87)$ & $(37.93)$ & $(95.97)$ & $(168.06)$ & $\{0.00\}^{\mathrm{a}}$ & $\{0.00\}^{\mathrm{a}}$ & $\{0.00\}^{\mathrm{a}}$ \\
2 & 10.83 & 51.61 & 88.60 & 11.95 & 51.40 & 93.84 & 7.38 & 28.98 & 54.94 \\
& $(36.54)$ & $(137.05)$ & $(165.41)$ & $(33.03)$ & $(93.09)$ & $(145.73)$ & $\{0.01\}^{\mathrm{a}}$ & $\{0.00\}^{\mathrm{a}}$ & $\{0.00\}^{\mathrm{a}}$ \\
3 & 19.96 & 78.64 & 199.87 & 19.84 & 78.38 & 166.84 & 10.05 & 46.64 & 95.03 \\
& $(71.17)$ & $(141.82)$ & $(517.17)$ & $(51.66)$ & $(123.55)$ & $(249.15)$ & $\{0.01\}^{\mathrm{b}}$ & $\{0.00\}^{\mathrm{a}}$ & $\{0.00\}^{\mathrm{a}}$ \\
Highest & 14.02 & 59.26 & 98.56 & 14.83 & 60.12 & 94.39 & 9.34 & 34.95 & 42.29 \\
& $(38.76)$ & $(112.19)$ & $(219.81)$ & $(36.82)$ & $(102.23)$ & $(180.92)$ & $\{0.01\}^{\mathrm{a}}$ & $\{0.00\}^{\mathrm{a}}$ & $\{0.00\}$ \\
\hline
\end{tabular}

\footnotetext{
${ }^{\mathrm{a}, \mathrm{b}}$ Statistical significance at $1 \%$ and $5 \%$ level, respectively.
} 
Figure 1A. The Expected Mean and Volatility in Unseasoned Equity Offe rings

The development in expected mean and volatility are shown for the average buy-and-hold return. The development in average buy-and-hold returns is shown in Panel A and C for wealth relative market-to-equity offering $\left(W_{m, T} / W_{i, T}\right)$ and equity offering-to-market $\left(W_{i, T} / W_{m, T}\right)$, respectively. In panels $\mathrm{B}$ and $\mathrm{D}$, the cross-sectional average buy-and-hold return are decomposed in a transformed mean component, $e^{\alpha_{T} T}-1$, and in a volatility component, $e^{1 / 2 \sigma_{T}^{2} \cdot T}-1$. The volatility component is independent of whether wealth relative $\left(W_{m, T} / W_{i, T}\right)$ and $\left(W_{i, T} / W_{m, T}\right)$ are used, and the volatility component has a positive influence on the average long-horizon wealth relative performance. The transformed mean component of the buy-and-hold return depends on the used transformation of wealth relatives.
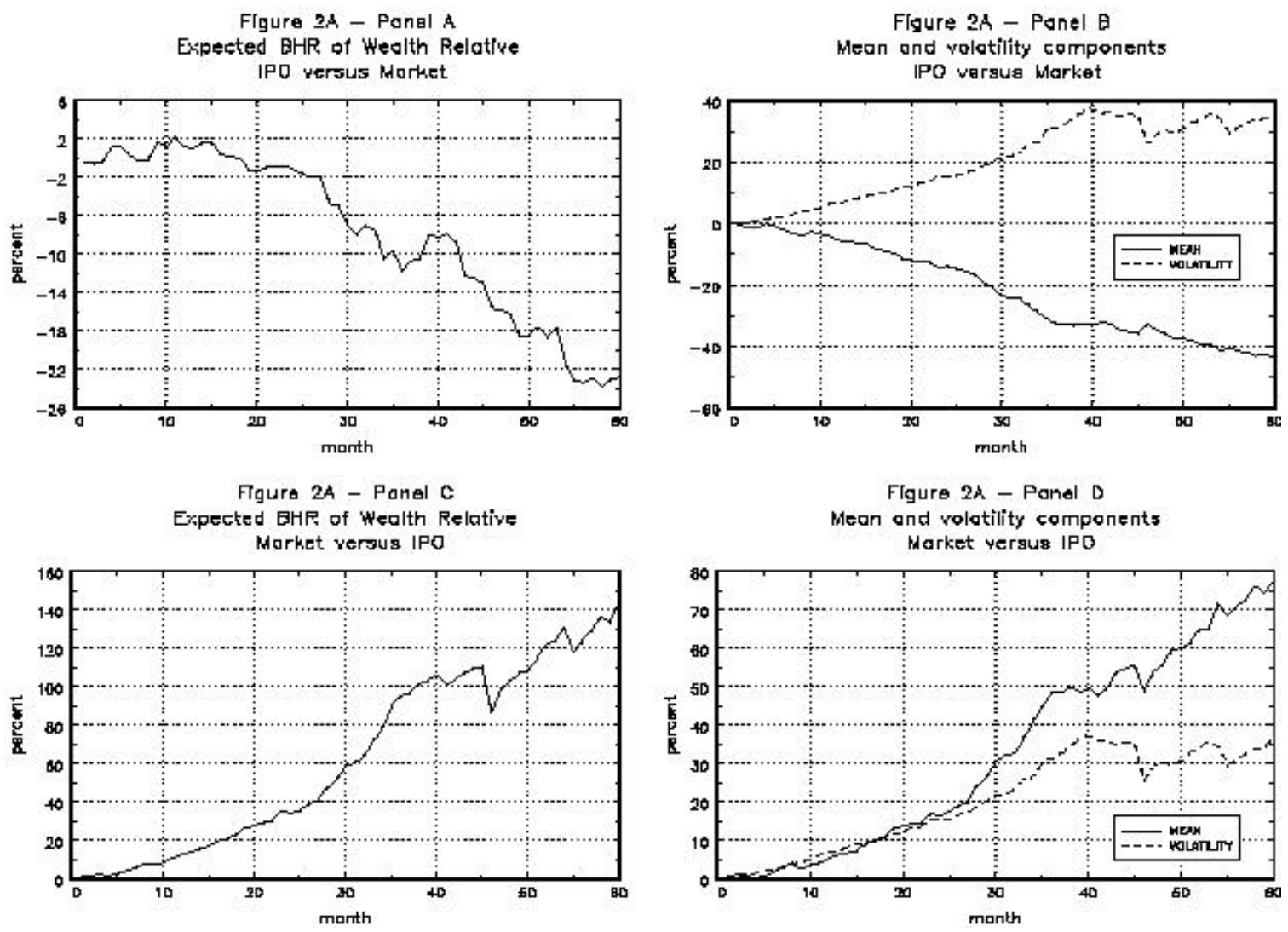
Figure 1B. The Expected Mean and Volatility in Seasoned Equity Offerings.

The development in expected mean and volatility are shown for the average buy-and-hold return. The development in average buy-and-hold returns is shown in Panel A and C for wealth relative market-to-equity offering $\left(W_{m, T} / W_{i, T}\right)$ and equity offering-to-market $\left(W_{i, T} / W_{m, T}\right)$, respectively. In panels $\mathrm{B}$ and $\mathrm{D}$, the cross-sectional average buy-and-hold return are decomposed in a transformed mean component, $e^{\alpha_{T} \cdot T}-1$, and in a volatility component, $e^{1 / 2 \sigma_{T}^{2} \cdot T}-1$. The volatility component is independent of whether wealth relative $\left(W_{m, T} / W_{i, T}\right)$ and $\left(W_{i, T} / W_{m, T}\right)$ are used, and the volatility component has a positive influence on the average long-horizon wealth relative performance. The transformed mean component of the buy-and-hold return depends on the used transformation of wealth relatives.
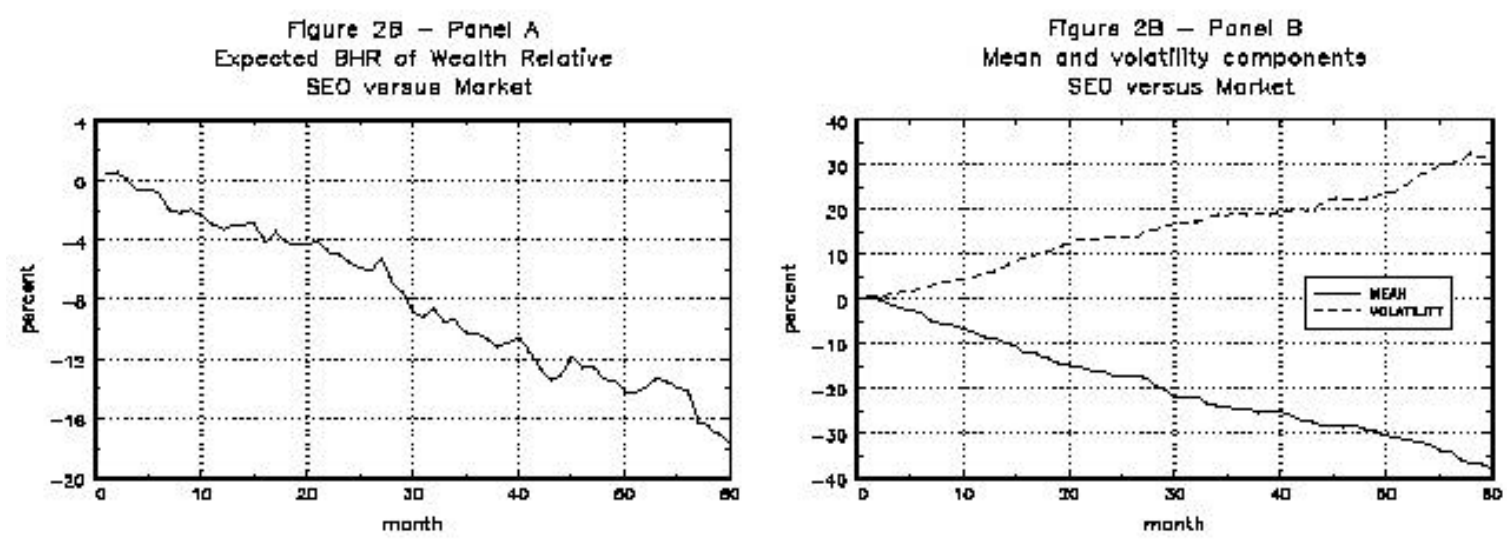

Figure 28 - Panel 0 Expected BHR of Wealth Relative Market varaua SEO
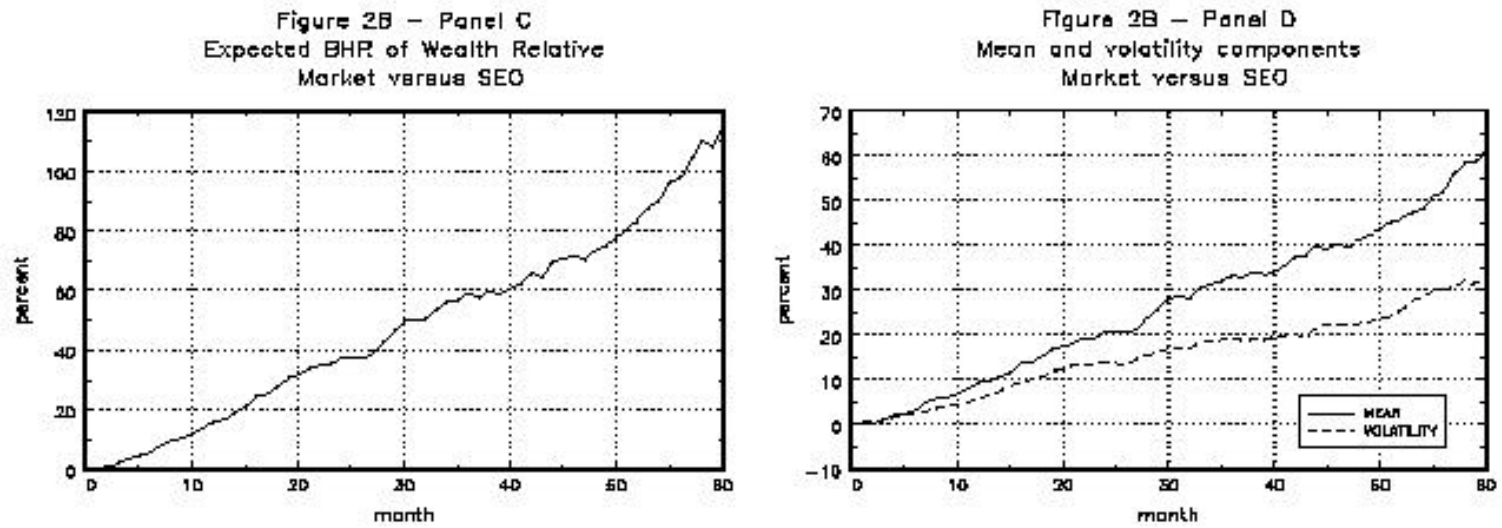


\section{Figure 2 Test of the Volatility-Adjusted Security Performance}

We test the maximum likelihood estimate $\alpha_{T}$ T. The test is $\mathrm{H}_{0}: \alpha_{T} \cdot T=0, \mathrm{H}_{1}: \alpha_{T} \cdot T \neq 0$ where $T=\{1, \ldots 60\}$. The maximum likelihood estimate $\alpha_{T} T$ is shown as 95 percent marginal confidence intervals. The transformed mean component $e^{\alpha_{T} \cdot T}-1$ for the wealth relative $\left(W_{i, T} / W_{m, T}\right)$ and its confidence intervals are shown in panel $\mathrm{A}$ and $\mathrm{C}$, respectively. The volatility component $e^{1 / 2 \sigma_{T}^{2} \cdot T}-1$ and its confidence intervals are shown in panel $\mathrm{B}$. The volatility component is the same whether the wealth relative $\left(W_{m, T} / W_{i, T}\right)$ or $\left(W_{i, T} / W_{m, T}\right)$ is used and therefore it can be considered with both panel A and $\mathrm{C}$.

Fígure 3 - Panel A: Mean camponent IPO Yereus Market

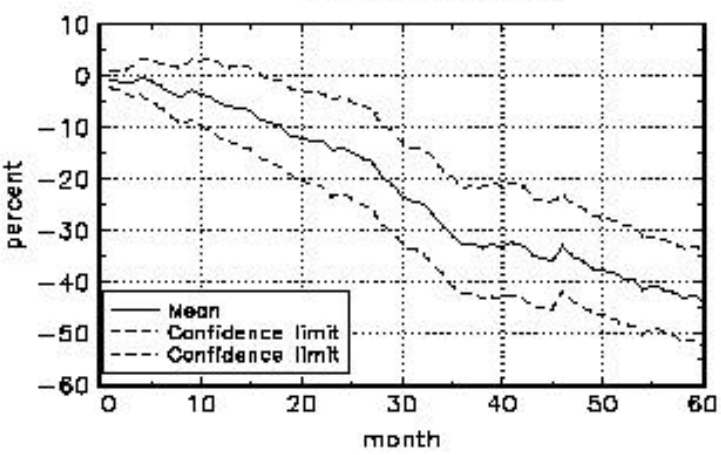

Flgure 3 - Panel C: Mean component SEO varsug Market

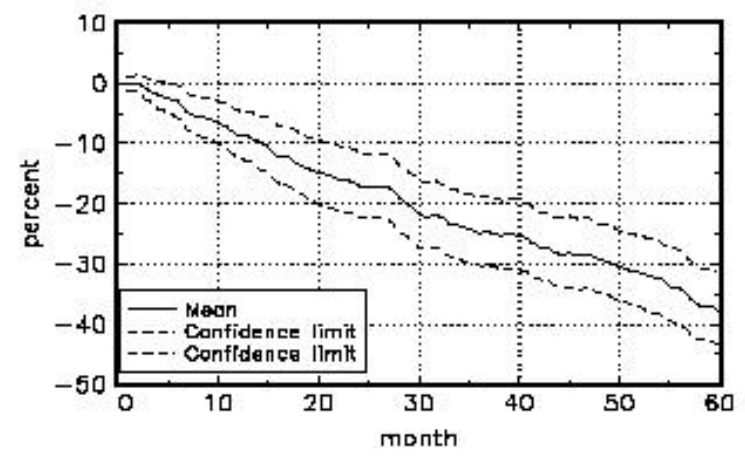

Figure 3 - Panel B: Volatility camponent IPO versus Harket

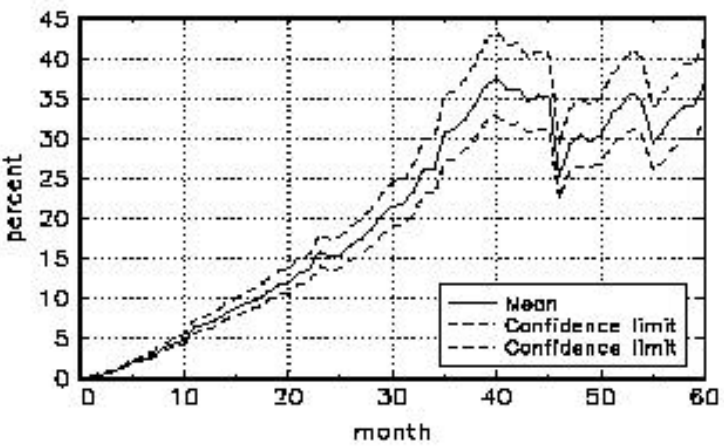

Figure 3 - Panel D: Volatility companent SEQ veraus Market

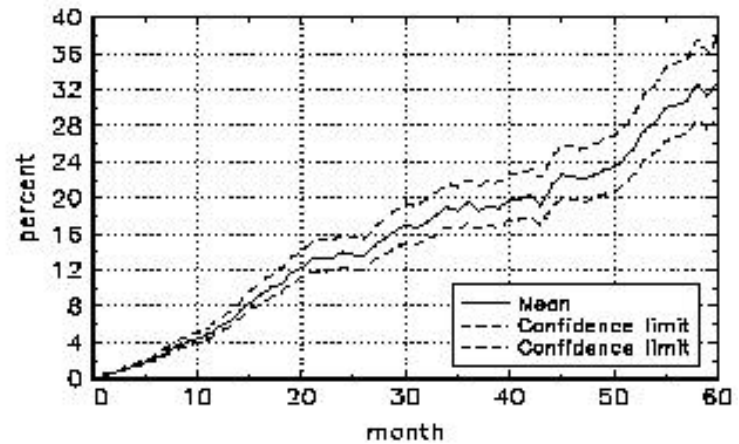

